\title{
Financial Reform and Banking Crises
}

\author{
Choudhry Tanveer Shehzad \\ Jakob De Haan
}

\author{
CESIFO WORKING PAPER NO. 2870 \\ CATEGory 7: MONETARy POLICY AND INTERNATIONAL FinANCE \\ DECEMBER 2009
}
An electronic version of the paper may be downloaded
- from the SSRN website: www.SSRN.com
- from the RePEc website: - from the CESifo website: www.CESifo-group.org/wp




\title{
Financial Reform and Banking Crises
}

\begin{abstract}
We examine the impact of various dimensions of financial reform on the likelihood of systemic and non-systemic banking crises. Using new financial reform measures for a large sample of developing and developed countries for the period 1973 to 2002, our multivariate probit modeling results suggest that conditional on adequate banking supervision, certain dimensions of financial reform reduce the likelihood of systemic crises. We also show that after a country has reformed, the introduction of further reforms becomes easier and leads to more stable financial systems. We also find some evidence that the likelihood of non-systemic crisis increases after financial reform.
\end{abstract}

JEL Code: E44, G21, G28, F36.

Keywords: banking crises, financial reform, financial fragility.

Choudhry Tanveer Shehzad
Department of Finance
Faculty of Economics \& Business
University of Groningen
P.O. Box 800
9700 AV Groningen
The Netherlands
c.t.shehzad@rug.nl

\author{
Jakob De Haan \\ Faculty of Economics and Business \\ University of Groningen \\ PO Box 800 \\ 9700 AV Groningen \\ The Netherlands \\ jakob.de.haan@rug.nl
}

November 2009

We are highly grateful to Abdul De Guia Abiad from the International Monetary Fund for his generous permission to let us use his data on financial liberalization. The authors are thankful to Jan Jacobs, Laura Spierdijk, Robert Lensink, and participants in seminars at the Netherlands Bank, the University of Groningen, the Annual Conference of the Royal Economic Society, 2009, Surrey, United Kingdom, the Annual Conference of European Economic Association 2009, Barcelona, Spain, the 2nd International Research Forum (2009) of the Europlace Institute of Finance, Paris, France, the XVII International Tor Vergata Conference on Banking and Finance, 2008, Rome, Italy and the workshop at CERES Summer School, 2009, Nijmegen, the Netherlands for their valuable suggestions. The usual disclaimer applies. Views expressed in this paper do not necessarily coincide with those of the Netherlands Bank or the State Bank of Pakistan. 


\section{Introduction}

Financial reform can be defined as measures aiming at the removal of noncompetitive market forces in the financial sector, thereby increasing its level of liberalization. Consequently, financial reform improves financial sector development, which, in turn, may enhance economic growth. At the same time, there is some evidence that increasing liberalization induces risk-taking behavior and may cause banking crises (cf. Kaminsky and Reinhart, 1999; Mehrez and Kaufmann, 2000). However, previous studies did not consider the conditioning impact of supervisory control or the overall level of financial liberalization in analyzing the impact of reform on the likelihood of crises. Moreover, the financial liberalization data used in these studies was quite limited and rather subjective. We employ a better methodology and an extensive new data set of financial reform recently provided by Abiad et al. (2008) to examine the impact of financial reform on banking crises. Our findings suggest that certain dimensions of financial reform reduce the likelihood of systemic banking crises-defined as crises in which much or all bank capital has been exhausted-conditional on adequate banking supervision. This result is broadly in line with the finding of Beck et al. (2006) that the presence of regulatory policies and institutions that discourage competition are associated with greater banking system fragility. We also find that once a country has reformed, the introduction of further reforms becomes easier and leads to more stable financial systems. This implies that there is a "learning effect" which has also been pointed out by Abiad and Mody (2005) in a different context. Moreover, we find some evidence that the likelihood of non-systemic crises-defined as crises limited to a small number of banks-increases after financial reform enhancing liberalization. These results therefore suggest that increased competition due to the financial reform may lead to the elimination of some inefficient financial institutions.

We analyze the impact of financial reform on systemic and non-systemic banking crises in 85 countries during the period 1973 to 2002. Our data on banking crises come from Honahan and Laeven (2005). Our indicator of financial form is based on the data set of Abiad et al. (2008) indicating the extent to which a financial system is liberalized. ${ }^{2}$ This is an extended and updated version of the

\footnotetext{
${ }^{2}$ The dataset of Abiad et al. (2008) covers 91 countries and a longer period, but many other explanatory variables are not available for all countries, thereby restricting our sample.
} 
database as used by Abiad and Mody (2005), covering various dimensions of the financial system. The measures relate to the presence of (i) credit controls and reserve requirements, (ii) interest rate controls, (iii) entry barriers, (iv) state ownership in the banking sector, (v) capital account restrictions, (vi) prudential regulation and supervision of the banking sector, and (vii) securities market policy.

We address the following research questions: (1) does financial reform, conditional on supervisory control, affect the likelihood of a systemic banking crisis, and if so, are there differences among the various dimensions of financial reform that we distinguish? (2) Does the impact of financial reform on banking crises vary at different levels of liberalization of the financial system? and (3) Are systemic and non-systemic crises affected in the same way by financial reform leading to more liberalization?

The rest of the paper is organized as follows. Section 2 provides a discussion on the determinants of banking crises and a brief literature review. It also introduces our measures for financial reform and banking crises. Section 3 describes the specification of our model and explains other explanatory variables used in our analysis. Section 4 analyses the impact of financial reform on the likelihood of systemic crises. Section 5 examines whether the impact of financial reform is conditioned by the level of liberalization. Section 6 deals with the impact of financial liberalization on non-systemic crises. Finally, section 7 offers a discussion of our results and their policy implications.

\section{Financial reform and banking crisis}

\subsection{Previous studies}

Demirgüç-Kunt and Detragiache (1998) analyze the relationship between banking crises and policies aimed at increasing financial liberalization using data over the period 1980-95 for 53 countries. Their findings suggest that banking crises are more likely to occur in liberalized financial systems. They also find that the impact of financial liberalization on a fragile banking sector is weaker where the institutional environment is strong. The indicator of financial reform used by Demirgüç-Kunt and Detragiache (1998) is a dummy variable taking a value of one for the first year in which some interest rates were liberalized. Although interest rate liberalization is 
important, it only covers a minor part of financial sector reform. Furthermore, this indicator does account for policy reversals.

Mehrez and Kaufmann (2000) examine how absence of corruption ('transparency') affects the probability of a financial crisis. Using multivariate probit modeling for 56 countries during 1977-97, they report a higher probability of a crisis following financial reform during the following five years. Moreover, they find that the crisis probability is higher in countries with poor transparency than in countries that are transparent. Mehrez and Kaufmann (2000) provide their own dating of financial reform and construct their reform measure on the basis of these dates.

Focusing on the link between currency and banking crises, Kaminsky and Reinhart (1999) analyze 76 currency crises and 26 banking crises for 20 countries during 1970 to mid-1995. One of their main findings is that financial reform enhancing liberalization often precedes banking crises. Their proxy for increased financial liberalization is two-year lagged domestic credit growth. Again, this is a poor proxy as increased credit growth may also be caused by various other factors than financial reform and it does not capture the diversity of financial reform.

On the basis of a panel analysis, Caprio and Martinez (2000) find that government ownership of banks increases the likelihood of banking crisis. However, Barth et al. (2004) using cross-country analysis, do not find that government ownership is significantly associated with increases in bank fragility once they control for the regulatory and supervisory environment.

There are also various papers that do not explicitly include policies aiming at financial liberalization as a potential determinant of banking crises. A good example is the recent study by Beck et al. (2006) who examine the impact of bank concentration, bank regulations, and national institutions on the likelihood that a country experiences a systemic banking crisis. They use data from 1980 to 1997 for 69 countries and report that crises are less likely in economies with more concentrated banking systems. Moreover, they find that regulatory policies and institutions that discourage competition are associated with greater banking system fragility. 


\subsection{Data}

The studies discussed above use different indicators of banking crises. Our indicator of banking crises is based on the Honohan and Laeven (2005) dataset that updates the work by Caprio and Klingebiel (1999), distinguishing between systemic and non-systemic banking crises that have occurred since the late 1970s. To the best of our knowledge, this is the most comprehensive database on banking crises. ${ }^{3}$ In our analysis of the relationship between (systemic and non-systemic) banking crises and financial reform we use a sample of 85 countries during 1973 to 2002. This selection is primarily dictated by the availability of the financial liberalization index, to be discussed hereafter, and the availability of control variables. Table A1 in the Appendix identifies the years in which the countries in our sample had a crisis.

Our data on financial liberalization come from Abiad et al. (2008) who distinguish seven dimensions of the extent to which the financial sector has been liberalized that are graded on scale from 3 (fully liberalized) to 0 (not liberalized). Apart from distinguishing between different dimensions of financial liberalization on an annual basis, the database has the advantage that it allows for policy reversals. The first dimension of liberalization refers to credit controls and excessively high reserve requirements (referred to as credit controls henceforth) focusing on the presence of specific credit ceilings or floors, and reserve requirements. The second dimension is about interest rate controls examining whether they are administered by the government, and whether there are floors, ceilings or bands present. The third dimension is entry barriers, which is based on licensing requirements and restrictions on geographical outreach activities. The fourth dimension covers state ownership in the banking sector, i.e., the share of the assets of the banking sector controlled by state-owned banks. The fifth dimension refers to capital account restrictions and other restrictions on international capital flows. The sixth dimension captures prudential regulations and supervision of the banking sector, including compliance with the Basel standards, and executive influence on the banking supervisory agency. The final dimension refers to

\footnotetext{
${ }^{3}$ Caprio and Klingebiel (1999) define a systemic banking crisis as a crisis in which much or all bank capital been exhausted. Honohan and Laeven (2005) use the same definition. A non-system banking crisis is a crises limited to a small number of banks. We could not use the updated dataset provided
} 
securities market policy covering the auctioning of government securities, debt and equity market development, and openness to foreign investors.

Abiad et al. (2008) acknowledge that the dimension referring to the supervision and prudential regulation of banks is different from the other dimensions of financial liberalization. A higher score in this case means better (or more) regulation. So in our empirical analysis, we do not treat this as a dimension of financial liberalization. We also exclude it in calculating our overall liberalization measure, which consists of the sum of the scores of the various liberalization dimensions excluding supervision.

Figure 1 shows the growth of the different financial liberalization measures and the financial supervision measure over the period of 1973-2005, differentiating between high-income OECD countries and other countries. As follows from Figure 1 , the average level of financial liberalization has increased over time, but the financial systems of high-income OECD countries are more liberalized than those of other countries in the sample and they are better supervised as well. Still, the gap between the two groups of countries has decreased over the 1973-2005 period for all liberalization dimensions, except for securities markets and capital controls. However, while financial systems in non-high-income OECD countries have been liberalized substantially, their supervisory control systems have evolved more slowly and the gap with high-income OECD countries has increased. As our results suggest that supervisory control should be complementary to financial reform enhancing liberalization, weaknesses in this respect may result in financial vulnerability.

We take the change of the various liberalization measures as our indicators of financial reform. Table A2 in the appendix shows Spearman's rank correlation coefficients between the different indicators of financial reform. It follows that the various dimensions of financial reform clearly differ from one another.

by Laeven and Valencia (2008) as it does not distinguish between systemic and non-systemic crises, while the duration of the crises is also not available. 
Figure 1. Financial liberalization and supervision in high-income OECD and other countries
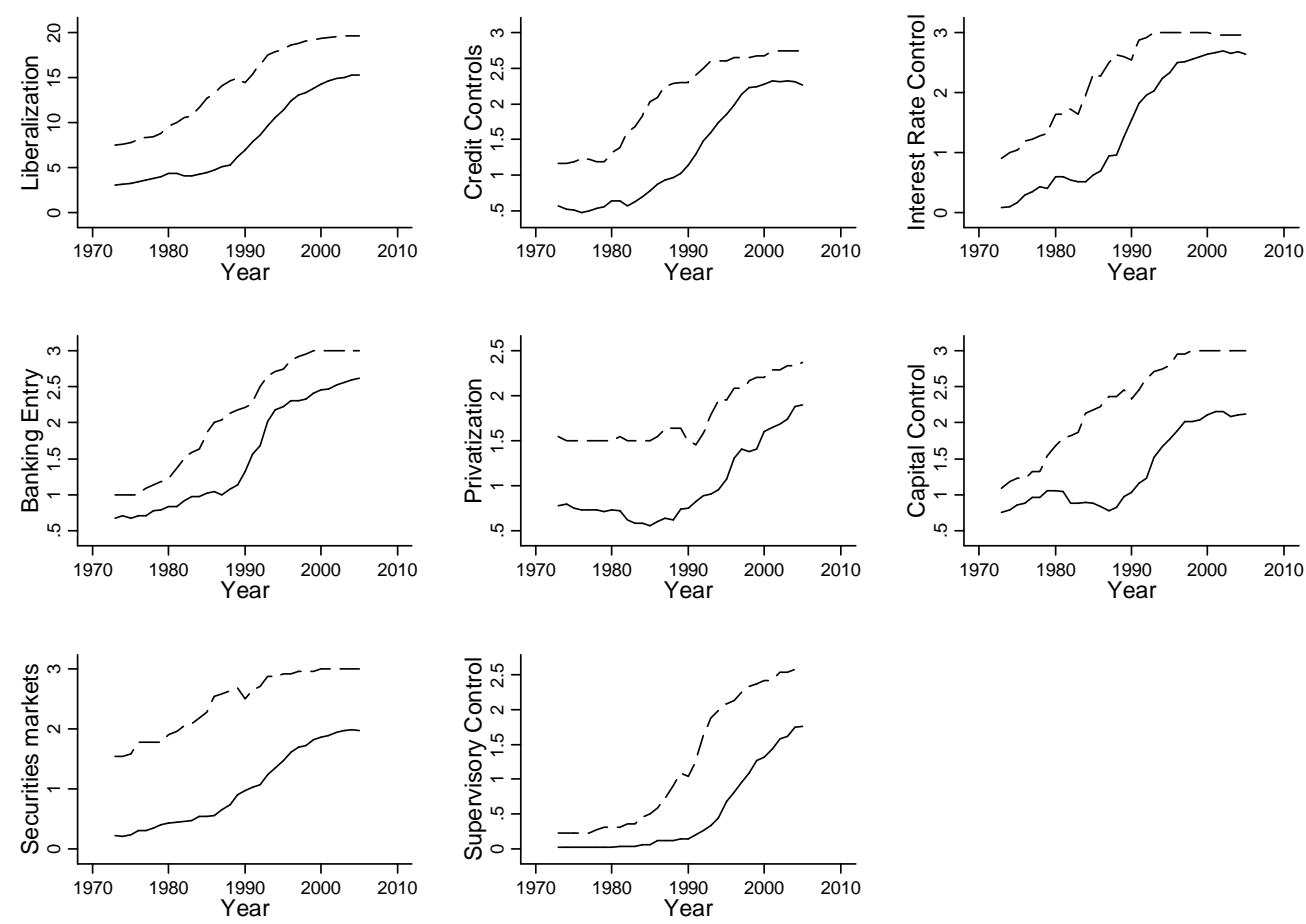

This figure presents trends in (different types of) financial liberalization and bank supervision in high-income OECD and other countries over the period 1973-2005. The dashed lines represent financial liberalization and supervisory control for high-income OECD countries while the solid lines refer to other countries in our sample.

\section{Model specification}

To analyze the impact of financial liberalization on systemic and non-systemic banking crises, we estimate the following model:

$$
\begin{aligned}
\mathbf{C r i s i s}_{i, t}=\alpha_{i, t} & +\lambda\left(\mathbf{L i b}_{i, 0}\right)+\psi\left[\sum_{t=1}^{-4}(\Delta \mathbf{L i b})_{i}\right]+\theta\left(\mathbf{S u p}_{i, t}\right)+\eta\left[\sum_{t=1}^{-4}(\Delta \mathbf{L i b})_{i}\right] *\left(\mathbf{S u p}_{i, t}\right) \\
& +\gamma\left(\mathbf{C t r l}_{i, t}\right)+\xi_{i, t}
\end{aligned}
$$

The dependent variable Crisis $_{i, t}$ takes a value of 1 if there is a banking crisis and zero if there is no crisis. In section 4 the dependent variable refers to systemic crisis, while in section 6 the dependent variable refers to non-systemic crisis. ${ }^{4}$ The

\footnotetext{
${ }^{4}$ Following previous studies, we assume that banking crises do not lead to a new regime so that the model does not suffer from the Lucas critique. However, during a banking crisis the impact of the
} 
likelihood of a crisis in country $i$ at time $t$ is a function of the initial level of liberalization ( $\mathbf{L} \mathbf{i b}_{i, 0}$ ); reform, taken here as the cumulative change in the level of any liberalization dimension over the current and last four years period $\left(\sum_{t=1}^{-4}(\Delta \mathbf{L i b})_{i}\right)$; the level of supervisory control $\left(\mathbf{S u p}_{i, t}\right)$; and a matrix of control variables $\left(\mathbf{C t r l}_{i, t}\right)$. Following Mehrez and Kaufmann (2000), we examine the impact of reform measures taken over a five-years period on the likelihood of a banking crisis thereby minimizing potential problems of endogeneity. To check for the conditioning effect of banking supervision, we introduce an interaction term of financial reform with the level of supervision.

Models with interactive terms cannot be interpreted directly on the basis of the coefficients of the constituent or interaction terms and their significance (Aiken and West, 1991; Brambor et al., 2006; and Shehzad et al., 2010). Therefore, we follow the approach suggested by Aiken and West (1991) for non-linear models. If $\Phi$ is the standard normal cumulative distribution and $\mathrm{X}_{\mathrm{i}, \mathrm{t}}$ denotes the explanatory variables in equation (1) then the conditional mean of the crisis variable can be written as:

$$
\begin{aligned}
E\left[\operatorname{Pr}(\mathbf{C r i s i s})_{i, t}\right. & \left.\mid \mathbf{X}_{i, t}\right]=\Phi\left[\alpha_{i, t}+\lambda\left(\mathbf{L i b}_{i, 0}\right)+\psi\left[\sum_{t=1}^{-4}(\Delta \mathbf{L i b})_{i}\right]+\theta\left(\mathbf{S u p}_{i, t}\right)+\eta\left[\sum_{t=1}^{-4}(\Delta \mathbf{L i b})_{i}\right] *\left(\mathbf{S u p}_{i, t}\right)\right. \\
& \left.+\gamma\left(\mathbf{C t r l}_{i, t}\right)\right]=\Phi(.)
\end{aligned}
$$

The key hypothesis to test for the marginal effect of financial reform on the probability of a crisis, conditional on supervisory control, is:

$$
\begin{aligned}
& \mathrm{H}_{0}=\frac{\partial \Phi(.)}{\partial\left[\sum_{t=1}^{-4}(\Delta \mathbf{L i b})_{i}\right]}=\psi \Phi(.)+\eta \Phi(.) *\left(\operatorname{Sup}_{i, t}\right)=0 \\
& \mathrm{H}_{1}=\frac{\partial \Phi(.)}{\partial\left[\sum_{t=1}^{-4}(\Delta \mathbf{L i b})_{i}\right]}=\psi \Phi(.)+\eta \Phi(.)^{*}\left(\operatorname{Sup}_{i, t}\right) \neq 0
\end{aligned}
$$

right-hand side variables may be different than during normal times. We will address this issue later in the paper. 
Where $\psi \Phi($.$) refers to the direct marginal effect of \sum_{t=1}^{-4}(\Delta \mathbf{L i b})_{i}$ and $\eta \Phi($.$) refers$ to the marginal effect of the interaction term. The stated hypothesis tests the total marginal impact of $\sum_{t=1}^{-4}(\Delta \mathbf{L i b})_{i}$ which may vary at different levels of supervisory control.

To address our second research question, we interact financial reforms with the level of liberalization. The resulting model can identify whether the impact of financial reform on systemic crises varies at different levels of liberalization. The corresponding model is:

$$
\begin{aligned}
\operatorname{Crisis}_{i, t}=\alpha_{i, t}^{\tau} & +\psi^{\tau}\left[\sum_{t=1}^{-4}(\Delta \mathbf{L i b})_{i}\right]+\theta^{\tau}\left(\mathbf{S u p}_{i, t}\right)+\pi\left(\mathbf{L i b}_{i, t}\right)+\eta^{\tau}\left[\sum_{t=1}^{-4}(\Delta \mathbf{L i b})_{i}\right]^{*}\left(\mathbf{L i b}_{i, t}\right) \\
& +\gamma^{\tau}\left(\mathbf{C t r l}_{i, t}\right)+\zeta_{i, t}
\end{aligned}
$$

If $\Phi$ is the standard normal cumulative distribution and $\mathbf{X}_{i, t}^{\Gamma}$ denotes all explanatory variables in equation (3), the conditional mean of the crisis variable can be written as:

$$
\begin{gathered}
E\left[\operatorname{Pr}(\mathbf{C r i s i s})_{i, t} \mid \mathbf{X}_{i, t}^{\Gamma}\right]=\Phi\left[\alpha_{i, t}^{\tau}+\psi^{\tau}\left[\sum_{t=1}^{-4}(\Delta \mathbf{L i b})_{i}\right]+\theta^{\tau}\left(\mathbf{S u p}_{i, t}\right)+\pi\left(\mathbf{L i b}_{i, t}\right)+\eta^{\tau}\left[\sum_{t=1}^{-4}(\Delta \mathbf{L i b})_{i}\right]^{*}\left(\mathbf{L i b}_{i, t}\right)\right. \\
\left.+\gamma^{\tau}\left(\mathbf{C t r l}_{i, t}\right)\right]=\Phi(\kappa)
\end{gathered}
$$

The key hypothesis to test for the marginal effect of financial reform on the probability of a crisis, conditional on different levels of liberalization, can be derived from equation (4) as:

$$
\begin{aligned}
& \mathrm{H}_{0}=\frac{\partial \Phi(\kappa)}{\partial\left[\sum_{t=1}^{-4}(\Delta \mathbf{L i b})_{i}\right]}=\psi^{\tau} \Phi(\kappa)+\eta^{\tau} \Phi(\kappa) *\left(\mathbf{L i b}_{i, t}\right)=0 \\
& \mathrm{H}_{1}=\frac{\partial \Phi(\kappa)}{\partial\left[\sum_{t=1}^{-4}(\Delta \mathbf{L i b})_{i}\right]}=\psi^{\tau} \Phi(\kappa)+\eta^{\tau} \Phi(\kappa)^{*}\left(\mathbf{L i b}_{i, t}\right) \neq 0
\end{aligned}
$$

Where $\psi^{\tau} \Phi(\kappa)$ refers to the direct marginal effect of $\sum_{t=1}^{-4}(\Delta \mathbf{L i b})_{i}$ and $\eta^{\tau} \Phi(\kappa)$ refers to the marginal effect of the interaction term. The stated hypothesis 
tests the total marginal impact of $\sum_{t=1}^{-4}(\Delta \mathbf{L i b})_{i}$ which may vary at different levels of liberalization.

We include various control variables following previous studies like Kaminsky and Reinhart (1999), Beck et al. (2006), and Demirgüç-Kunt and Detragiache (2002). These variables include real GDP growth (one-year lagged), the rate of inflation ${ }^{5}$ (change in $\mathrm{CPI}$ ), the real interest, and the depreciation of the exchange rate. Finally, we include initial level of real GDP per capita (in US\$) to control for the level of economic development, and the initial level of financial liberalization. Table 1 summarizes the control variables and Table A3 in the appendix gives a list of our dependent and independent variables ${ }^{6}$ and also provides their sources and expected signs.

\begin{tabular}{|l|l|l|l|l|l|}
\hline \multicolumn{7}{|c}{ Table 1. Summary statistics } \\
\hline \multicolumn{1}{|c|}{ Variable } & \multicolumn{1}{c|}{ Mean } & \multicolumn{1}{c|}{ Standard Deviation } & \multicolumn{1}{l|}{ Minimum } & Maximum & Observations \\
\hline Systemic crises & 0.189 & 0.392 & 0 & 1 & 1459 \\
\hline Non-systemic crises & 0.070 & 0.255 & 0 & 1 & 1459 \\
\hline Liberalization (overall) & 11.742 & 6.062 & 0 & 21 & 1459 \\
\hline Credit controls & 1.826 & 1.058 & 0 & 3 & 1459 \\
\hline Interest rate control & 2.101 & 1.216 & 0 & 3 & 1459 \\
\hline Banking entry & 1.912 & 1.131 & 0 & 3 & 1459 \\
\hline Privatization & 1.411 & 1.191 & 0 & 3 & 1459 \\
\hline Supervisory control & 0.888 & 0.979 & 0 & 3 & 1459 \\
\hline Capital controls & 1.870 & 1.088 & 0 & 3 & 1459 \\
\hline Securities markets & 1.734 & 1.076 & 0 & 3 & 1459 \\
\hline Real GDP growth & 0.033 & 0.038 & -0.14 & 0.17 & 1459 \\
\hline Log (GDP/capita) & 8219.502 & 9572.304 & 93.01 & 38200.41 & 1459 \\
\hline Real interest rate & 7.256 & 24.615 & -97.81 & 789.80 & 1459 \\
\hline Inflation & 0.104 & 0.130 & -0.11 & 0.99 & 1459 \\
\hline Depreciation & -2.331 & 55.211 & -1848.73 & 1.00 & 1459 \\
\hline Economic freedom index & 24.919 & 5.432 & 9.56 & 36.85 & 1347 \\
\hline Openness & 64.535 & 38.696 & 6.32 & 368.01 & 1436 \\
\hline Bank concentration & 0.671 & 0.206 & 0.20 & 1.00 & 827 \\
\hline Corruption & 3.636 & 1.436 & 0.00 & 6.00 & 1169 \\
\hline Money and quasi-money/GDP & 92.444 & 764.187 & 4.70 & 18798.83 & 1188 \\
\hline Credit to private sector/GDP & 0.518 & 0.428 & 0.01 & 3.45 & 1390 \\
\hline & & & & \\
\hline
\end{tabular}

\footnotetext{
${ }^{5}$ The inflation rate (p) is transformed by the formula $(\mathrm{p} / 100) /(1+(\mathrm{p} / 100))$ to reduce the influence of extreme observations.

${ }^{6}$ Data for certain variables, like bank concentration, corruption, money and quasi-money to GDP ratio, and credit to private sector, was not available for the whole period of analysis. Introducing these variables leads to a considerably smaller sample.
} 
Table A4 in the Appendix shows the correlation matrix of the control variables, liberalization measures, and our indicators of banking crises. The table shows that the control variables are not highly correlated.

\section{Financial liberalization and systemic banking crisis}

\subsection{Main results}

For the analysis of our first research question, i.e., what is the impact of financial liberalization on systemic banking crises conditional on supervisory control, we estimate equation (1) using a probit model with random effects. ${ }^{7}$ Table 2 shows the results, while the outcomes for testing the hypotheses are shown in Figure 2.

Instead of reporting marginal effects at means, we report average marginal effects as suggested by Bartus (2005) and Cameron and Trivedi (2009). According to these authors, marginal effects computed at means are not good approximations of average marginal effects. Sample means used for the calculation of marginal effects at means might refer to either non-existent or inherently nonsensical observations. Moreover, average marginal effects are more meaningful and easy to interpret.

In column (1), we regress systemic banking crises on control variables only, without using any financial reform measure or interactions. Our findings are in line with those of previous studies and the estimated coefficients are in accordance with the expected signs as shown in Table A2. Real GDP growth, initial GDP/capita, real interest rate, the initial level of liberalization, and depreciation turn out to be significant.

In column (2), we introduce our indicator of overall financial reform. It turns out that the interaction term of overall financial reform with supervision appears significant and has a negative sign. Economically, the effect is modest but still it clearly has a negative impact on the likelihood of systemic crises and in our later tests this effect remains quite robust.

In the remaining columns of Table 2 we include the various dimensions of financial reform separately one by one. We observe that the interaction terms of

\footnotetext{
${ }^{7}$ We cannot use conditional logit or fixed effect models, because initial GDP per capita and initial level of liberalization are time-invariant variables. Furthermore, these techniques drop those countries that did not face any crisis during the sample period. Arellano and Hahn (2007) and Green (2004) show that the probit estimator is also not well behaved in the presence of fixed effects.
} 
supervision and reforms come up significant except for barriers to entry and securities market reforms. Moreover, all these interaction effects have negative signs.

However, as mentioned before, inference based on the coefficient of financial reform or the interaction term only is insufficient and can lead to deceptive findings. ${ }^{8}$ So we provide the marginal effects of financial reforms and their confidence intervals (at 5 percent level of significance) in Figure 2. For a marginal effect of reform to be significantly positive (or negative), the marginal effect as well as the upper and lower bound should be in a positive (or negative) quadrant. As the figures show, when supervisory control improves, the effect of financial reform further reduces the likelihood of systemic crises and this effect is significant especially at higher levels of supervisory control. However, this conclusion does not hold for reforms improving bank entry and securities market reforms, which appear insignificant.

Consequently, our results suggest that most dimensions of financial reform reduce the likelihood of systemic crises, conditional on adequate banking supervision. The Wald chi-square tests and Likelihood ratio tests indicate joint significance of our models at the $1 \%$ level of significance.

How well do our models correctly predict crises? To examine this issue, we use Brier Scores. ${ }^{9}$ Brier Scores can be calculated as

$$
\frac{\sum_{i=1}^{N} \sum_{t=1}^{T}\left[\text { Crisis }_{i, t}-\operatorname{Pr}(\text { Crisis })_{i, t}\right]^{2}}{N^{*} T}
$$

Where Crisis $_{i, t}$ is the actual dummy which takes a value of 1 if there is a crisis and 0 if there is no crisis in country $i$ at time $t$ and $\operatorname{Pr}(\text { Crisis })_{i, t}$ is the estimated probability of a crisis in country $i$ at time $t$. A perfect forecast will result in a Brier score of 0 . A forecast that is always wrong will yield a Brier Score of 1 , while a forecast that is correct in 50 percent will result in a Brier Score of 0.25. The Brier Score of our models is around 0.14 , which indicates that our model is performing well.

\footnotetext{
${ }^{8}$ A similar logic applies to supervisory control and its interaction terms.
} 


\subsection{Endogeneity}

Even though we follow Mehrez and Kaufmann (2000) and examine the impact of reform measures taken over period prior to a crisis, the results presented in section 4.1 may suffer from an endogeneity problem, because supervisors may liberalize or reverse the liberalization of their financial systems in the wake of a crisis. We test for this problem using a two-step probit model with endogenous regressors. ${ }^{10}$ Our main objective is to control for reverse causality. In order to keep the model simple, we drop the interaction terms. The results of the exercise do not suggest that our findings are caused by reverse causality.

We use two instrument variables. The first one is from the economic freedom index dataset from the Fraser Institute (Gwartney and Lawson, 2008). The economic freedom index data is available from 1970 onwards and has several dimensions of economic freedom like size of government (expenditure, taxes and enterprises), legal structure and security of property rights, access to sound money, freedom to trade internationally and regulation of credit, labor, and business. We drop those dimensions of the economic freedom index that are very similar to our financial liberalization measures. The basic intuition for using this proxy is that financial sector reforms are often part of a broader economic reform program. Secondly, we use the openness of the economy (computed as the sum of exports and imports as a percentage of GDP) as an instrument. We average both instruments over five years.

We check the validity of our instruments by the Amemiya-Lee-Newey minimum chi-square test under the null hypothesis that the used group of instruments is valid, i.e., they are uncorrelated with the error term in the structural equation. As shown in the bottom panel of Table A5 in the appendix, we cannot reject the null hypothesis indicating that our set of instrument is valid. Next, we apply the Wald test of exogeneity under the null hypothesis that the instrumented variable is exogenous. The results as shown in Table A5 suggest that none of the reform measures appears endogenous.

An alternative check on endogeneity was performed, dropping all the observations after the start of a crisis (keeping the first year only) until the end of the crisis and re-estimating the models shown in Table 2. This hardly affects our

\footnotetext{
${ }^{9}$ See Schmidt and Griffith (1998) for a detailed discussion on Brier Scores.
} 
main conclusions (results available on request). This approach, following Barrell et al. (2009), also deals with a possible objection that the impact of our control variables on the likelihood of a crisis will be different during a crisis.

${ }^{10}$ We implement the two-step probit model with endogenous regressors and use robust standard errors for the clustering over countries. 


\begin{tabular}{|c|c|c|c|c|c|c|c|c|c|}
\hline \multicolumn{10}{|c|}{ Table 2. Effect of financial reform on systemic crises } \\
\hline & & $(1)$ & $(2)$ & $(3)$ & $(4)$ & $(5)$ & $(6)$ & $(7)$ & $(8)$ \\
\hline \multirow[t]{2}{*}{ Real GDP growth $(t-1)$} & Coefficient & $-1.092 * * *$ & $-1.136^{* * *}$ & $-1.235 * * *$ & $-1.158^{* * *}$ & $-1.232 * * *$ & $-1.103^{* * *}$ & $-1.192 * * *$ & $-1.227 * * *$ \\
\hline & S.E. & 0.221 & 0.25 & 0.256 & 0.251 & 0.256 & 0.249 & 0.253 & 0.257 \\
\hline \multirow[t]{2}{*}{ Log (initial GDP/capita) } & Coefficient & $-0.056 * * *$ & $-0.061^{* * *}$ & $-0.059^{* * *}$ & $-0.062^{* * *}$ & $-0.059 * * *$ & $-0.064 * * *$ & $-0.058^{* * *}$ & $-0.058^{* * *}$ \\
\hline & S.E. & 0.02 & 0.021 & 0.02 & 0.021 & 0.02 & 0.021 & 0.02 & 0.02 \\
\hline \multirow[t]{2}{*}{ Real interest rate } & Coefficient & $0.002^{* * *}$ & $0.002 * * *$ & $0.002 * * *$ & $0.002^{* * *}$ & $0.002 * * *$ & $0.002 * * *$ & $0.002^{* * *}$ & $0.002^{* * *}$ \\
\hline & S.E. & 0.001 & 0.001 & 0.001 & 0.001 & 0.001 & 0.001 & 0.001 & 0.001 \\
\hline \multirow[t]{2}{*}{ Inflation } & Coefficient & 0.032 & 0.064 & 0.081 & 0.097 & 0.076 & 0.027 & 0.062 & 0.079 \\
\hline & S.E. & 0.107 & 0.111 & 0.11 & 0.11 & 0.11 & 0.111 & 0.11 & 0.11 \\
\hline \multirow[t]{2}{*}{ Depreciation } & Coefficient & $0.179 * *$ & $0.142 *$ & $0.156^{* *}$ & $0.152^{* *}$ & $0.166^{* *}$ & $0.160^{* *}$ & $0.153^{* *}$ & $0.163^{* *}$ \\
\hline & S.E. & 0.075 & 0.076 & 0.076 & 0.076 & 0.076 & 0.076 & 0.075 & 0.076 \\
\hline \multirow[t]{2}{*}{ Initial liberalization } & Coefficient & $-0.019 * *$ & $-0.021^{* *}$ & $-0.021^{* *}$ & $-0.019 * *$ & $-0.020 * *$ & $-0.020 * *$ & $-0.021 * *$ & $-0.020 * *$ \\
\hline & S.E. & 0.009 & 0.009 & 0.009 & 0.009 & 0.009 & 0.009 & 0.009 & 0.009 \\
\hline \multirow{2}{*}{ Supervisory Control (SC) } & Coefficient & 0.009 & $0.039^{* *}$ & $0.025^{*}$ & 0.016 & 0.009 & $0.026^{*}$ & $0.024 *$ & 0.013 \\
\hline & S.E. & 0.013 & 0.017 & 0.015 & 0.014 & 0.015 & 0.014 & 0.014 & 0.015 \\
\hline \multirow[t]{2}{*}{ Financial reform (overall) (LR) } & Coefficient & & -0.004 & & & & & & \\
\hline & S.E. & & 0.005 & & & & & & \\
\hline \multirow[t]{2}{*}{$S C * \mathbf{L R}$} & Coefficient & & $-0.017^{* * *}$ & & & & & & \\
\hline & S.E. & & 0.006 & & & & & & \\
\hline \multirow[t]{2}{*}{ Credit controls reform (CR) } & Coefficient & & & 0.013 & & & & & \\
\hline & S.E. & & & 0.014 & & & & & \\
\hline \multirow[t]{2}{*}{$\mathrm{SC}^{*} \mathrm{CR}$} & Coefficient & & & $-0.032 * *$ & & & & & \\
\hline & S.E. & & & 0.016 & & & & & \\
\hline \multirow[t]{2}{*}{ Interest rate control reform (IR) } & Coefficient & & & & -0.019 & & & & \\
\hline & S.E. & & & & 0.012 & & & & \\
\hline \multirow[t]{2}{*}{ SC*IR } & Coefficient & & & & $-0.044^{* *}$ & & & & \\
\hline & S.E. & & & & 0.019 & & & & \\
\hline \multirow[t]{2}{*}{ Banking entry reform (BR) } & Coefficient & & & & & -0.011 & & & \\
\hline & S.E. & & & & & 0.016 & & & \\
\hline \multirow[t]{2}{*}{$\mathrm{SC}^{*} \mathrm{BR}$} & Coefficient & & & & & 0.019 & & & \\
\hline & S.E. & & & & & 0.017 & & & \\
\hline Privatization reform (PR) & Coefficient & & & & & & -0.03 & & \\
\hline
\end{tabular}




\begin{tabular}{|c|c|c|c|c|c|c|c|c|c|}
\hline & S.E. & & & & & & 0.02 & & \\
\hline \multirow[t]{2}{*}{$S C * P R$} & Coefficient & & & & & & $-0.044 * *$ & & \\
\hline & S.E. & & & & & & 0.019 & & \\
\hline \multirow[t]{2}{*}{ Capital controls reform (CapR) } & Coefficient & & & & & & & -0.01 & \\
\hline & S.E. & & & & & & & 0.015 & \\
\hline \multirow[t]{2}{*}{ SC*CapR } & Coefficient & & & & & & & $-0.038^{* *}$ & \\
\hline & S.E. & & & & & & & 0.017 & \\
\hline \multirow[t]{2}{*}{ Securities markets reforms (SR) } & Coefficient & & & & & & & & -0.004 \\
\hline & S.E. & & & & & & & & 0.021 \\
\hline \multirow[t]{2}{*}{$S C * S R$} & Coefficient & & & & & & & & 0.005 \\
\hline & S.E. & & & & & & & & 0.021 \\
\hline No. of Observations & & 1559 & 1459 & 1459 & 1459 & 1459 & 1459 & 1459 & 1459 \\
\hline No. of Countries & & 85 & 85 & 85 & 85 & 85 & 85 & 85 & 85 \\
\hline Wald Chi-squared & & $72.735 * * *$ & $87.484 * * *$ & $75.001^{* * *}$ & $86.585 * * *$ & $72.434 * * *$ & $90.322 * * *$ & $82.027 * * *$ & $72.130 * * *$ \\
\hline L Ratio Test & & $198.398 * * *$ & $202.367 * * *$ & $201.493^{* * *}$ & $200.785^{* * *}$ & $199.773 * * *$ & $211.488^{* * *}$ & $202.104 * * *$ & $195.743^{* * *}$ \\
\hline Brier Score & 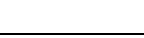 & 0.142 & 0.14 & 0.142 & 0.141 & 0.142 & 0.141 & 0.14 & 0.142 \\
\hline
\end{tabular}




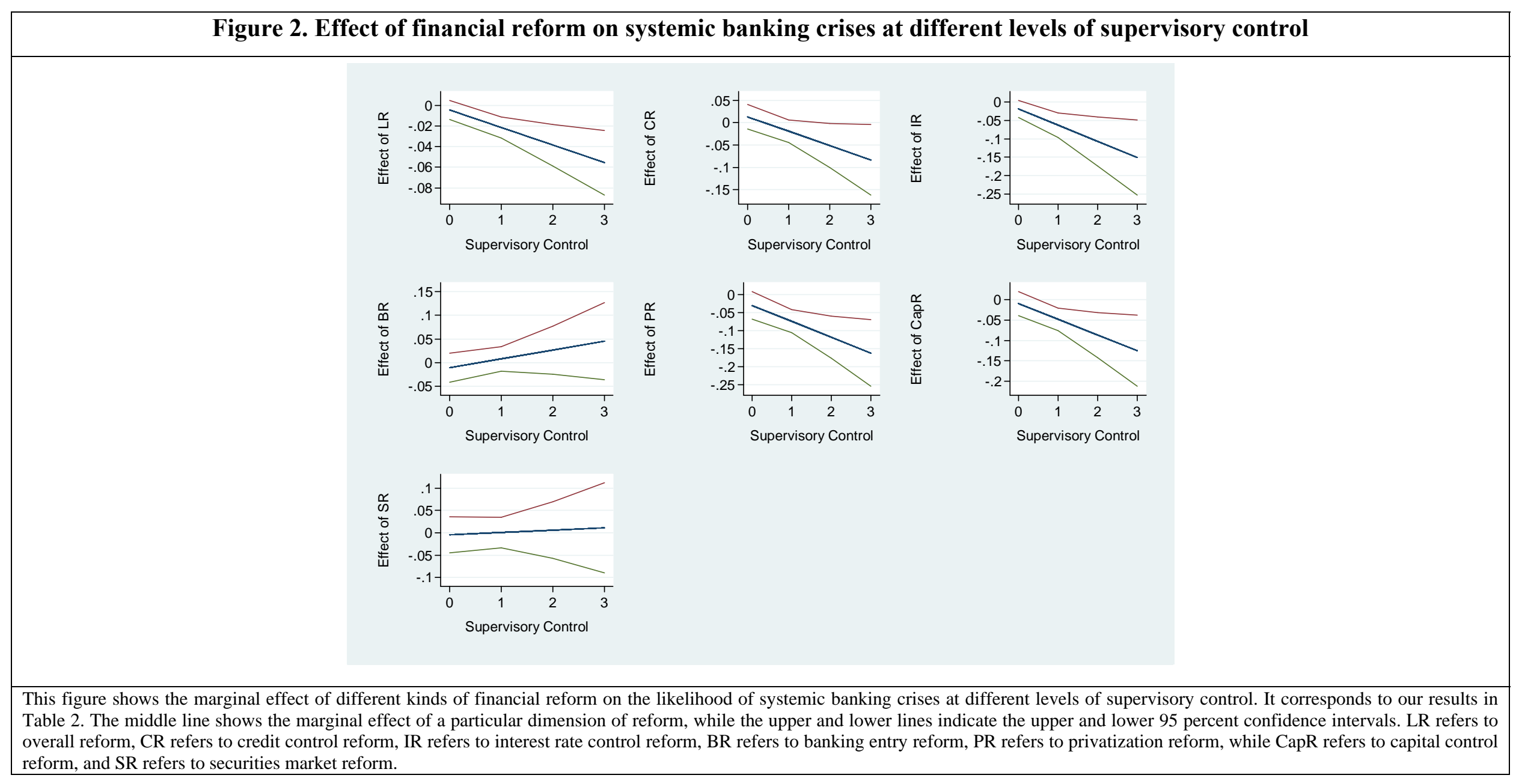




\begin{tabular}{|c|c|c|c|c|c|c|c|c|c|}
\hline \multicolumn{10}{|c|}{ Table 3. Effect of financial reform on systemic crises conditional on the level of liberalization } \\
\hline & & $(1)$ & $(2)$ & (3) & $(4)$ & $(5)$ & $(6)$ & $(7)$ & (8) \\
\hline \multirow[t]{2}{*}{ Real GDP growth } & Coefficient & $-1.034^{* * *}$ & $-1.057^{* * *}$ & $-1.141^{* * *}$ & $-1.110^{* * *}$ & $-1.161^{* * *}$ & $-1.065 * * *$ & $-1.108^{* * *}$ & $-1.175^{* * *}$ \\
\hline & S.E. & 0.215 & 0.243 & 0.248 & 0.246 & 0.249 & 0.244 & 0.245 & 0.251 \\
\hline \multirow[t]{2}{*}{ Initial GDP/capita } & Coefficient & $-0.076^{* * *}$ & $-0.082 * * *$ & $-0.074 * * *$ & $-0.079 * * *$ & $-0.075 * * *$ & $-0.083^{* * *}$ & $-0.077 * * *$ & $-0.075 * * *$ \\
\hline & S.E. & 0.019 & 0.02 & 0.019 & 0.019 & 0.019 & 0.02 & 0.019 & 0.019 \\
\hline \multirow[t]{2}{*}{ Real interest rate } & Coefficient & $0.002 * * *$ & $0.003 * * *$ & $0.002 * * *$ & $0.003 * * *$ & $0.002 * * *$ & $0.003^{* * *}$ & $0.002 * * *$ & $0.002 * * *$ \\
\hline & S.E. & 0.001 & 0.001 & 0.001 & 0.001 & 0.001 & 0.001 & 0.001 & 0.001 \\
\hline \multirow[t]{2}{*}{ Inflation } & Coefficient & 0.038 & 0.129 & 0.09 & 0.13 & 0.078 & 0.076 & 0.086 & 0.079 \\
\hline & S.E. & 0.104 & 0.109 & 0.107 & 0.109 & 0.107 & 0.109 & 0.106 & 0.107 \\
\hline \multirow[t]{2}{*}{ Depreciation } & Coefficient & $0.177^{* *}$ & $0.127 *$ & $0.142 *$ & $0.128^{*}$ & $0.157^{* *}$ & $0.154^{* *}$ & $0.147^{* *}$ & $0.156^{* *}$ \\
\hline & S.E. & 0.073 & 0.073 & 0.073 & 0.073 & 0.073 & 0.073 & 0.073 & 0.073 \\
\hline \multirow[t]{2}{*}{ Supervisory control } & Coefficient & 0.007 & -0.007 & 0.019 & -0.003 & 0.024 & 0.017 & 0.012 & 0.023 \\
\hline & S.E. & 0.016 & 0.018 & 0.017 & 0.018 & 0.017 & 0.017 & 0.017 & 0.017 \\
\hline \multirow[t]{2}{*}{ Level of liberalization } & Coefficient & 0 & $0.007 *$ & -0.001 & 0.003 & -0.004 & 0 & 0 & -0.003 \\
\hline & S.E. & 0.003 & 0.004 & 0.003 & 0.003 & 0.003 & 0.003 & 0.003 & 0.003 \\
\hline \multirow[t]{2}{*}{ Financial reform (overall) (LR) } & Coefficient & & 0.015 & & & & & & \\
\hline & S.E. & & 0.011 & & & & & & \\
\hline \multirow[t]{2}{*}{ Liberalization*LR } & Coefficient & & $-0.003^{* * *}$ & & & & & & \\
\hline & S.E. & & 0.001 & & & & & & \\
\hline \multirow[t]{2}{*}{ Credit controls reform (CR) } & Coefficient & & & $0.066^{* *}$ & & & & & \\
\hline & S.E. & & & 0.03 & & & & & \\
\hline \multirow[t]{2}{*}{ Liberalization*CR } & Coefficient & & & $-0.007 * *$ & & & & & \\
\hline & S.E. & & & 0.003 & & & & & \\
\hline \multirow[t]{2}{*}{ Interest rate control reform (IR) } & Coefficient & & & & $0.060^{*}$ & & & & \\
\hline & S.E. & & & & 0.033 & & & & \\
\hline \multirow[t]{2}{*}{ Liberalization*IR } & Coefficient & & & & $-0.010^{* * *}$ & & & & \\
\hline & S.E. & & & & 0.003 & & & & \\
\hline \multirow[t]{2}{*}{ Banking entry reform (BR) } & Coefficient & & & & & 0.005 & & & \\
\hline & S.E. & & & & & 0.033 & & & \\
\hline Liberalization*BR & Coefficient & & & & & 0 & & & \\
\hline
\end{tabular}




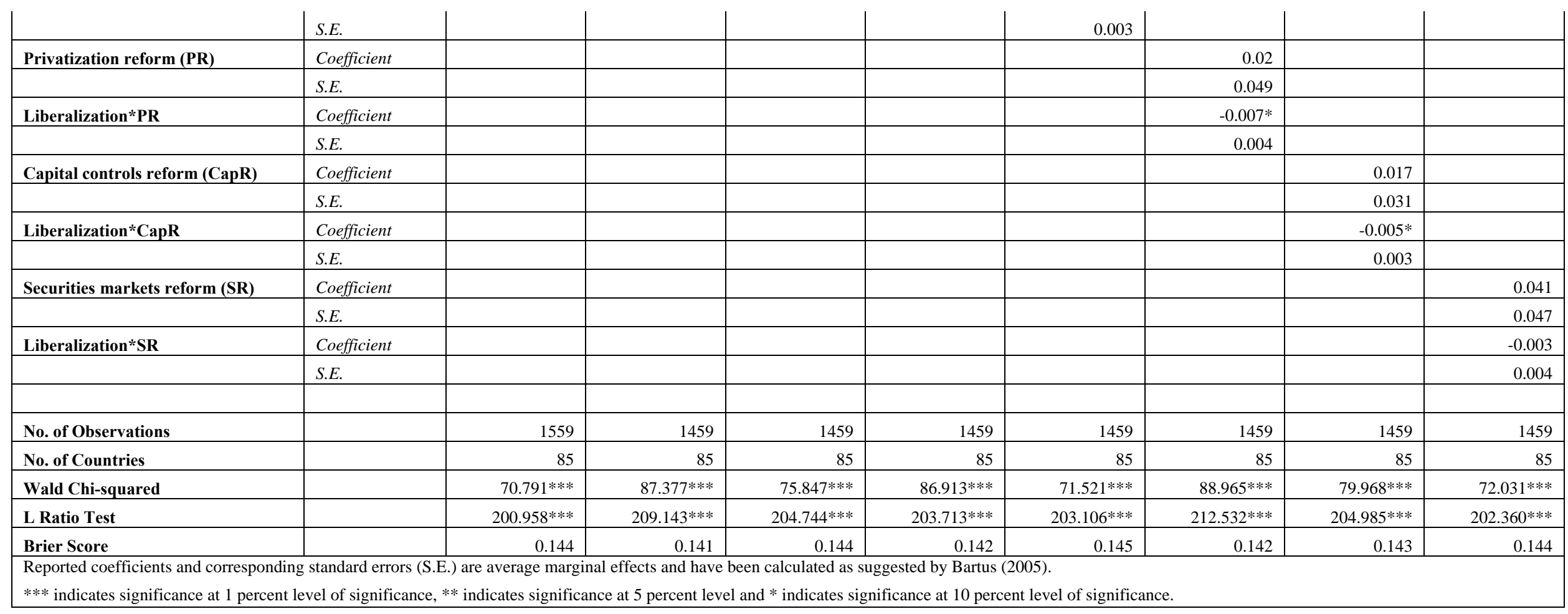




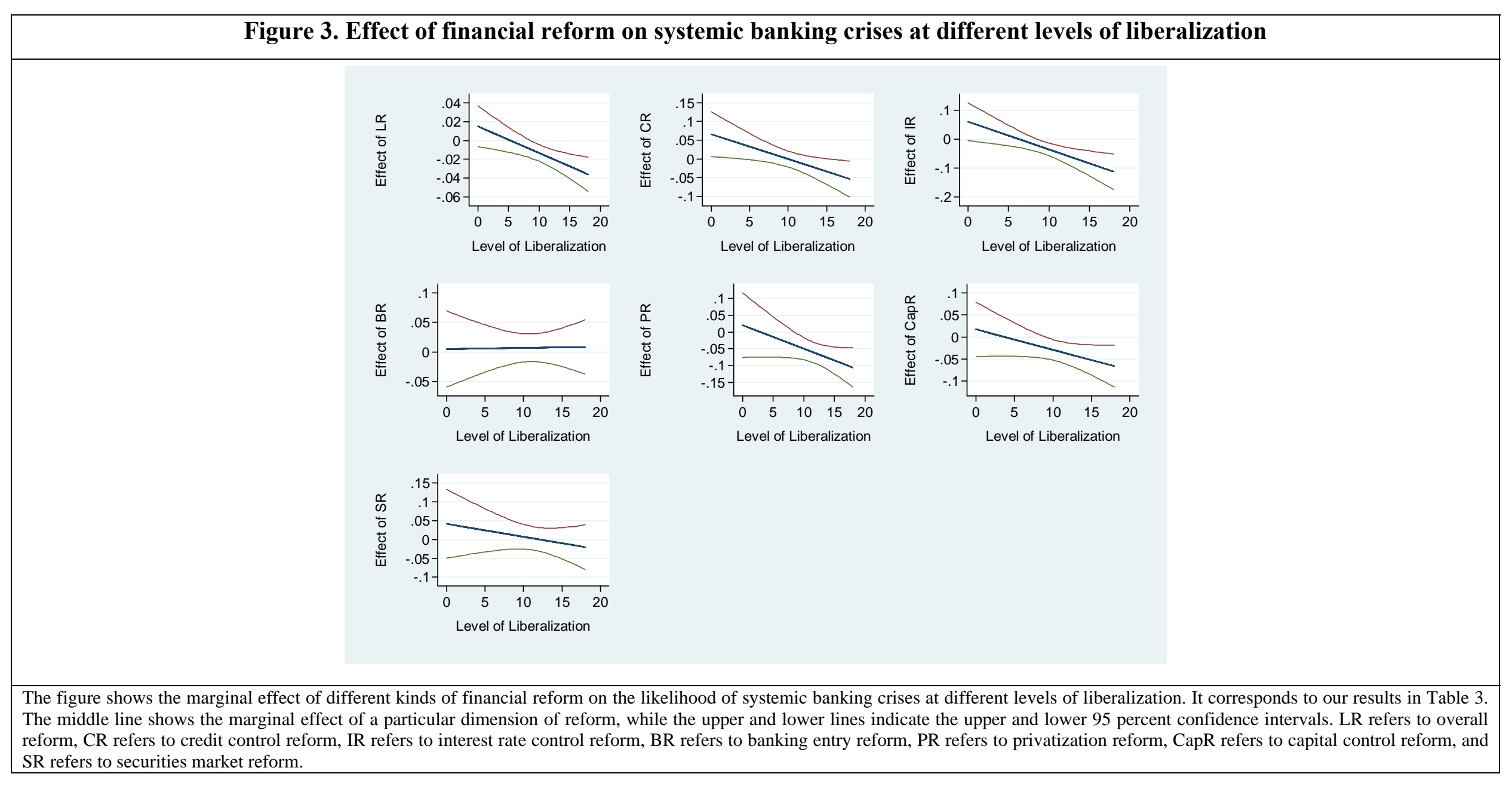




\begin{tabular}{|c|c|c|c|c|c|c|c|c|c|}
\hline \multicolumn{10}{|c|}{ Table 4. Effect of financial reform on non-systemic crises } \\
\hline & & (1) & (2) & $(3)$ & $(4)$ & (5) & $(6)$ & $(7)$ & $(8)$ \\
\hline \multirow[t]{2}{*}{ Real GDP growth $(t-1)$} & Coefficient & -0.027 & -0.029 & -0.026 & -0.028 & -0.027 & -0.036 & -0.025 & -0.036 \\
\hline & S.E. & 0.035 & 0.038 & 0.04 & 0.041 & 0.04 & 0.044 & 0.033 & 0.039 \\
\hline \multirow[t]{2}{*}{ Log (initial GDP/capita) } & Coefficient & 0 & 0 & 0 & 0.001 & 0 & 0.001 & 0 & 0.001 \\
\hline & S.E. & 0.003 & 0.003 & 0.003 & 0.003 & 0.003 & 0.003 & 0.003 & 0.003 \\
\hline \multirow[t]{2}{*}{ Real interest rate } & Coefficient & 0 & 0 & 0 & 0 & 0 & 0 & 0 & 0 \\
\hline & S.E. & 0 & 0 & 0 & 0 & 0 & 0 & 0 & 0 \\
\hline \multirow[t]{2}{*}{ Inflation } & Coefficient & -0.008 & -0.013 & -0.004 & -0.007 & -0.015 & -0.005 & -0.005 & -0.005 \\
\hline & S.E. & 0.017 & 0.021 & 0.019 & 0.02 & 0.022 & 0.019 & 0.016 & 0.017 \\
\hline \multirow[t]{2}{*}{ Depreciation } & Coefficient & 0.002 & 0.005 & 0.003 & 0.002 & 0.003 & 0.002 & 0.001 & 0.002 \\
\hline & S.E. & 0.007 & 0.011 & 0.01 & 0.008 & 0.01 & 0.006 & 0.006 & 0.007 \\
\hline \multirow[t]{2}{*}{ Initial liberalization } & Coefficient & 0.001 & 0.002 & 0.002 & 0.001 & 0.002 & 0.001 & 0.001 & 0.001 \\
\hline & S.E. & 0.001 & 0.002 & 0.002 & 0.001 & 0.002 & 0.001 & 0.001 & 0.001 \\
\hline \multirow[t]{2}{*}{ Supervisory Control (SC) } & Coefficient & 0.001 & -0.002 & 0.001 & 0.001 & 0 & 0.001 & -0.002 & 0 \\
\hline & S.E. & 0.002 & 0.002 & 0.002 & 0.002 & 0.002 & 0.002 & 0.002 & 0.002 \\
\hline \multirow[t]{2}{*}{ Financial reform (overall) (LR) } & Coefficient & & 0.001 & & & & & & \\
\hline & S.E. & & 0.001 & & & & & & \\
\hline \multirow[t]{2}{*}{$\mathbf{S C}^{*} \mathbf{L R}$} & Coefficient & & 0.001 & & & & & & \\
\hline & S.E. & & 0.001 & & & & & & \\
\hline \multirow[t]{2}{*}{ Credit controls reform (CR) } & Coefficient & & & 0.009 & & & & & \\
\hline & S.E. & & & 0.006 & & & & & \\
\hline \multirow[t]{2}{*}{$\mathrm{SC}^{*} \mathrm{CR}$} & Coefficient & & & -0.001 & & & & & \\
\hline & S.E. & & & 0.002 & & & & & \\
\hline \multirow[t]{2}{*}{ Interest rate control reform (IR) } & Coefficient & & & & 0.001 & & & & \\
\hline & S.E. & & & & 0.002 & & & & \\
\hline \multirow[t]{2}{*}{ SC*IR } & Coefficient & & & & 0.004 & & & & \\
\hline & S.E. & & & & 0.003 & & & & \\
\hline \multirow[t]{2}{*}{ Banking entry reform (BR) } & Coefficient & & & & & 0.014 & & & \\
\hline & S.E. & & & & & 0.009 & & & \\
\hline $\mathrm{SC}^{*} \mathrm{BR}$ & Coefficient & & & & & -0.001 & & & \\
\hline
\end{tabular}




\begin{tabular}{|c|c|c|c|c|c|c|c|c|c|}
\hline & S.E. & & & & & 0.002 & & & \\
\hline \multirow[t]{2}{*}{ Privatization reform (PR) } & Coefficient & & & & & & 0.002 & & \\
\hline & S.E. & & & & & & 0.003 & & \\
\hline \multirow[t]{2}{*}{$\mathrm{SC}^{*} \mathrm{PR}$} & Coefficient & & & & & & -0.001 & & \\
\hline & S.E. & & & & & & 0.002 & & \\
\hline \multirow[t]{2}{*}{ Capital controls reform (CapR) } & Coefficient & & & & & & & -0.002 & \\
\hline & S.E. & & & & & & & 0.002 & \\
\hline \multirow[t]{2}{*}{$\mathrm{SC}^{*} \mathrm{CapR}$} & Coefficient & & & & & & & 0.007 & \\
\hline & S.E. & & & & & & & 0.004 & \\
\hline \multirow[t]{2}{*}{ Securities markets reform (SR) } & Coefficient & & & & & & & & 0.002 \\
\hline & S.E. & & & & & & & & 0.003 \\
\hline \multirow[t]{2}{*}{$\mathrm{SC} * \mathrm{SR}$} & Coefficient & & & & & & & & 0.006 \\
\hline & S.E. & & & & & & & & 0.004 \\
\hline & & & & & & & & & \\
\hline No. of Observations & & 1559 & 1459 & 1459 & 1459 & 1459 & 1459 & 1459 & 1459 \\
\hline No. of Countries & & 85 & 85 & 85 & 85 & 85 & 85 & 85 & 85 \\
\hline Wald Chi-squared & & 4.807 & $41.847^{* * * *}$ & $29.712^{* * *}$ & 13.269 & $39.391^{* * *}$ & 4.228 & $29.118^{* * *}$ & $18.570^{* *}$ \\
\hline L Ratio Test & & 175.541 & $170.146^{* * *}$ & $168.891^{* * *}$ & 162.566 & $168.747^{* * *}$ & 156.234 & $169.283^{* * *}$ & $164.874 * *$ \\
\hline Brier Score & & 0.067 & 0.069 & 0.069 & 0.069 & 0.068 & 0.069 & 0.07 & 0.069 \\
\hline
\end{tabular}




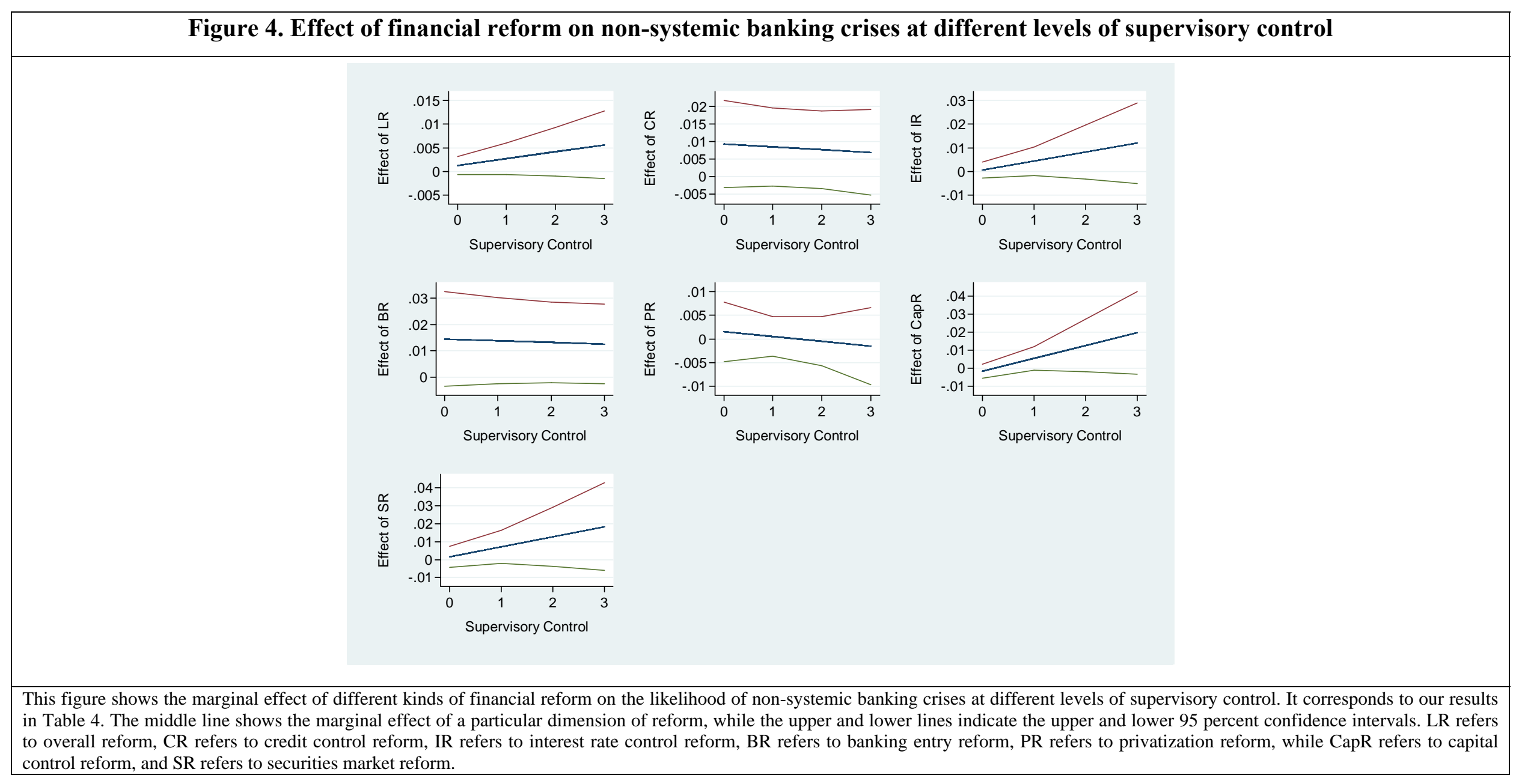




\subsection{Robustness}

We examine the robustness of our results presented in section 4.1 in a number of ways. These tests indicate that our results are not sensitive to changes in our sample and model specification.

Firstly, we restrict our sample to non-OECD countries. It reduces our number of observations from 1459 country-year observations for 85 countries to 944 country-year observations for 61 countries. The results are presented in Table A6 in the Appendix, while the corresponding tests of the hypotheses are shown in Figure A1 in the Appendix. The interaction effect of liberalization remains significant and negative, while the tests of the hypotheses are similar to those reported in Figure 2. The only change is that the interaction of privatization and supervisory control does not appear significant, but the corresponding hypothesis test does not change.

Secondly, we change the list of control variables by adding corruption as suggested by Mehrez and Kaufmann (2000), banking concentration as suggested by Beck et al. (2006), and two-year lagged credit to the private sector following Kaminsky and Reinhart (1999). Moreover, we add the ratio of money and quasimoney to GDP as a control variable, following a number of studies (e.g., Beck et al., 2006). In the specification where we introduce our corruption variable the period of analysis is restricted from 1984 to 2002. Corruption only appears significant at 10 percent level of significance in two models and our main results remain unaffected. When we introduce bank concentration as a control variable, the sample is reduced to 80 countries with 827 observations (against 1459 in main results). Bank concentration does not appear significant and our results hold except for credit controls reform, which becomes non-significant. When we introduce money and quasi-money, the sample of analysis is reduced to 1188 observations from 73 countries, but it does not affect our main results. The additional control variable appears insignificant. The introduction of two-year lagged credit to the private sector reduces the sample to 1370 observations from 80 countries and does not affect any of our results although the private sector credit variable appears significant. All results are available on request. 


\section{The role of the level of financial liberalization}

In this section, we argue that financial reform does not only have a direct impact on the likelihood of a crisis, but also an indirect impact. Initial reforms help various players in the financial institutions to learn about the process of liberalization and it makes the outcome of an adverse effect less likely in the aftermath of further reforms. Abiad and Mody (2005) labeled this as “Learning Effect”, albeit in a different context.

The main estimation results of equation (3) are presented in Table 3 and the graphical presentation of the testing of the hypotheses is shown in Figure 3. As shown in Table 3, the interaction effects of the level of liberalization with financial reforms appear significant with a negative sign. The overall models appear significant at 1 percent level of significance and the Brier Scores also indicate that the models are performing well.

The top-left graph in Figure 3 presents the impact of reform at different levels of liberalization. A first thing to note is that the effect of reforms on the likelihood of a crisis appears negative after a certain minimum level of liberalization has been reached. As financial systems become more liberalized, the negative impact on the likelihood of systemic crises of further financial reforms becomes significant. This suggests that financial systems learn from the process of liberalization and leads to less fragility in the long run.

The same result holds for various dimensions of reform. Removal of credit controls, interest rate controls, privatization, and capital account reform all contribute to a more stable banking sector.

\section{Are non-systemic crises different?}

With the introduction of more competition and transparency in the financial system through market-based reforms, it is very much likely that some inefficient banks are forced to close. Therefore, it seems likely that financial reform will have a different impact on non-systemic crises than on systemic crises. So far, most previous studies do not treat systemic and non-systemic crises differently. We are not aware of studies examining the impact of financial reform on non-systemic crises, even though the effect of financial reform on non-systemic crises is likely to differ from that on systemic crises. Modeling non-systemic crises is a difficult task for two 
reasons. First, there are many factors that can cause non-systemic crises depending on the heterogeneous specializations and ownership structures of banks ${ }^{11}$, and second, it is not necessary that these crises occur because of changes in macroeconomic or financial system variables. Still, we check whether financial reform affects the likelihood of non-systemic crises, thereby addressing our third research question. We estimate equation (1) using a panel probit model with nonsystemic crises as the dependent variable.

The results are shown in Table 4 and the corresponding hypothesis testing outcomes are presented in Figure 4. The models appear significant as indicated by Wald Chi-squared test and the Likelihood Ratio tests, except for the models shown in columns (1), (4), and (6). The macroeconomic variables that were significant in the model for systemic crises do not appear significant. Interestingly, the marginal effect of financial reform appears positive for non-systemic crises, although it is not significant. It points to important conclusions. First, systemic and non-systemic crises are driven by different factors and should be modeled accordingly. Second, the impact of financial reform on non-systemic crisis is very different from the impact of reform on systemic crises. If anything, financial reform increases the likelihood of non-systemic crises.

\section{Conclusions and policy implications}

We have examined the effect of (six dimensions of) financial reform on the likelihood of systemic and non-systemic banking crises. We find that reform that enhances liberalization reduces the likelihood of systemic crises, subject to appropriate supervisory control. Furthermore, financial systems learn from reform, which helps introducing further reforms without adverse outcomes. Moreover, we find that systemic and non-systemic crises are driven by different factors.

Our findings suggest the need to reconsider a widely shared view that has emerged in the wake of the current financial crisis, namely that strict regulation is needed for financial stability. Our results indicate that financial reform conditional on good supervisory control reduces the likelihood of systemic crises, and it therefore important to combine both policies in a meaningful way. In contrast,

\footnotetext{
${ }^{11}$ For example, Shehzad et al. (2010) show how ownership structures of banking firms affect their risk taking behavior.
} 
nowadays many observers seem to believe that reforms that have liberalized financial systems have played an important role in creating the current financial crises. Consequently, there may be a reversal of some of these liberalization measures in the wake of the crisis. However, as pointed out by Allen and Gale (2007), the extensive financial regulation introduced after the Great Depression not only led to the virtual disappearance of crises, it also seriously affected the efficiency of the financial system. Allen and Gale (2007) argue that the complete elimination of crises is neither optimal nor desirable, because it reduces the ability of financial institutions to perform their basic task of efficient allocation of resources. Excessive regulation reduces the incentives for banks to introduce new services and products. In view of the dynamic requirements of economies, the inability to introduce new products can result in sub-optimal risk hedging and exploitation of consumers. There is a possibility that history may repeat itself. Our results suggest that banking supervision needs to be improved but that the process of financial liberalization should not be reversed.

A potential danger highlighted by our results is the inadequate supervisory control in non-OECD economies. Financial reform in non-OECD countries has narrowed the liberalization gap with high-income OECD countries, but as far as supervision is concerned this gap has widened.

Our results also suggest that financial systems learn from reform, helping to create more stable banking systems. A reversal of liberalization will therefore also indirectly lead to more banking instability. 


\section{References}

Abiad, Abdul G., and Mody, Ashoka (2005), "Financial Reform: What Shakes It? What Shapes It?”, American Economic Review, 95 (1), 66-88.

Abiad, Abdul G., Tressel, Thierry and Detragiache, Enrica, (2008), “A New Database of Financial Reforms”, IMF Working Paper No. 08/266

Aiken, L., and S. West (1991), "Multiple Regression: Testing and Interpreting Interactions”, London: Sage Publications.

Allen F., and D. Gale (2007), “Understanding Financial Crises”, Oxford University Press, New York, USA.

Arellano, M., and J. Hahn (2007), “Understanding Bias in Nonlinear Panel Models: Some Recent Developments.” In: R. Blundell, W. Newey, and T. Persson (eds.), Advances in Economics and Econometrics, Ninth World Congress, Cambridge University Press.

Barrell, Ray, E. Philip Davis, Dilruba Karim and Iana Liadze (2009), "Bank regulation, Property Prices, and Early Warning Systems for Banking Crises in OECD Countries”, NIESR and Brunel University, mimeo.

Barth, James R., Gerard Caprio Jr., and Ross Levine (2004), "Bank Regulation and Supervision: What Works Best?” Journal of Financial Intermediation, 13, 205-248.

Bartus, Tamás, (2005). “Estimation of marginal effects using margeff,” Stata Journal, StataCorp LP, 5(3), 309-329.

Beck, Thorsten, Asli Demirgüç-Kunt, and Ross Levine (2006), "Bank Concentration, Competition, and Crises: First results”, Journal of Banking and Finance, 30, 1581-1603.

Brambor, T., W.R. Clark, and M. Golder (2006), "Understanding interaction models: improving empirical analyses”, Political Analysis 14, 1-20.

Cameron, Colin A. and Pravin K. Trivedi, (2009), "Microeconometrics using Stata”, Stata Press Publication, StataCorp LP, College Station, Texas 
Caprio Jr., Gerard, and E.A. Martinez (2000), “Avoiding Disaster: Policies to Reduce the Risk of Banking Crises”. Egyptian Centre for Economic Studies Working Paper No. 47.

Caprio, G., and D. Klingebiel (1999), "Episodes of Systemic and Borderline Financial Crises”, Mimeograph, The World Bank.

Demirgüç-Kunt, Asli and Enrica Detragiache (1998), “Financial Liberalization and Financial Fragility”, World Bank Policy Research Working Paper No 1917.

Demirgüç-Kunt, Asli and Enrica Detragiache (2000), "Monitoring Banking Sector Fragility: A Multivariate Logit Approach”, World Bank Economic Review, 14(2), 287-307.

Demirgüç-Kunt, Asli and Enrica Detragiachea (2002), "Does Deposit Insurance Increase Banking System Stability? An Empirical Investigation”, Journal of Monetary Economics, 49, 1373-1406.

Green, William (2004), “The Behaviour of the Maximum Likelihood Estimator of Limited Dependent Variable Models in the Presence of Fixed Effects”, Econometrics Journal, 7(1), 98-119.

Gwartney, James, Robert Lawson, and Seth Norton (2008), “Economic Freedom of the World, 2008 Annual Report”. The Fraser Institute, Data retrieved from www.freetheworld.com.

Honahan, Patrick and Luc A. Laeven (2005), "Systemic Financial Distress: Containment and Resolution”, Cambridge (UK): Cambridge University Press.

Kaminsky, Graciela L. (1999), “Currency and Banking Crises: The Early Warnings of Distress”, IMF Working Paper No. 99/178.

Laeven, Luc A. and Fabian V. Valencia (2008), “Systemic Banking Crises: A New Database”, IMF Working Paper No. 08/224

Mehrez, Gil and Daniel Kaufman (2000), “Transparency, Liberalization and Banking Crises”, World Bank Policy Research Working Paper No. 2286. 
Schmidt, C.H. and J.L. Griffith (1998), "Multivariate classification rules: Calibration and discrimination”. In Encyclopedia of Biostatistics, ed. P. Armitage and T. Colton, 2844-2850. New York: Wiley.

Shehzad, C. T., De Haan, J. and Scholtens, L.J.R., (2010), “The impact of bank ownership concentration on impaired loans and capital adequacy”, Journal of Banking and Finance, 34 (2), 399-408. 


\section{Appendix}

\section{Table A1. Systemic and non-systemic banking crises in our sample}

\begin{tabular}{|c|c|c|}
\hline Country: & Systemic crises: & Non-systemic crises: \\
\hline Albania & 1992-96 & \\
\hline Algeria & $1990-92$ & \\
\hline Argentina & 1980-82, 1989-90,1995, 2001-02 & \\
\hline Australia & & 1989-92 \\
\hline \multicolumn{3}{|l|}{ Austria } \\
\hline Azerbaijan & $1995-96$ & \\
\hline Bangladesh & $1988-96$ & \\
\hline Belarus & & $1995-02$ \\
\hline \multicolumn{3}{|l|}{ Belgium } \\
\hline Bolivia & 1986-88, 1994-02 & \\
\hline Brazil & 1990, 1994-99 & \\
\hline Britain & & 1974-76, 1980-89 \\
\hline Bulgaria & 1996-97 & \\
\hline Burkina-Faso & 1988-94 & \\
\hline Cameroon & 1987-93, 1995-98 & \\
\hline Canada & & 1983-85 \\
\hline Chile & $1976,1981-83$ & \\
\hline China & 1990-02 & \\
\hline Colombia & $1982-87$ & \\
\hline Costa Rica & $1994-96$ & \\
\hline Cote d'Ivoire & 1988-91 & \\
\hline Czech Republic & 1989-91, & \\
\hline Denmark & & $1987-92$ \\
\hline \multicolumn{3}{|l|}{ Dominican Rep } \\
\hline Ecuador & 1980-84, 1996-01 & \\
\hline Egypt & $1980-84$ & $1991-95$ \\
\hline El Salvador & 1989 & \\
\hline Estonia & $1992-95$ & 1998 \\
\hline Ethiopia & & $1994-95$ \\
\hline Finland & 1991-94 & \\
\hline France & & $1994-95$ \\
\hline Georgia & $1991-96$ & \\
\hline Germany & & $1976-79$ \\
\hline Ghana & $1982-89$ & $1997-02$ \\
\hline Greece & & $1991-95$ \\
\hline Guatemala & & 1990-02 \\
\hline Hong Kong & & 1982-86, 1988 \\
\hline Hungary & 1991-95 & \\
\hline India & & 1993-02 \\
\hline Indonesia & $1997-02$ & 1994 \\
\hline \multicolumn{3}{|l|}{ Ireland } \\
\hline Israel & $1977-83$ & \\
\hline Italy & & 1990-95 \\
\hline Jamaica & $1996-00$ & 1994 \\
\hline Japan & 1992-02 & \\
\hline Jordan & & $1989-90$ \\
\hline \multicolumn{3}{|l|}{ Kazakhstan } \\
\hline Kenya & 1985-89, 1992-95 & 1996-02 \\
\hline Korea & $1997-02$ & \\
\hline Kyrgyz Rep & 1990-02 & \\
\hline Latvia & $1995-96$ & \\
\hline Lithuania & $1995-96$ & \\
\hline
\end{tabular}




\begin{tabular}{|c|c|c|}
\hline Madagascar & 1988 & \\
\hline Malaysia & 1997-01 & 1985-88 \\
\hline Mexico & $1981-91,1994-00$ & \\
\hline Morocco & 1980-84 & \\
\hline Mozambique & $1987-95$ & \\
\hline Nepal & 1988 & \\
\hline \multicolumn{3}{|l|}{ Netherlands } \\
\hline New Zealand & & $1987-90$ \\
\hline Nicaragua & 1986-02 & \\
\hline Nigeria & 1991-95 & 1997 \\
\hline Norway & $1990-93$ & \\
\hline \multicolumn{3}{|l|}{ Pakistan } \\
\hline Paraguay & 1995-00 & 2001-02 \\
\hline Peru & $1983-90$ & \\
\hline Philippines & 1983-87, 1998-02 & \\
\hline Poland & 1992-95 & \\
\hline \multicolumn{3}{|l|}{ Portugal } \\
\hline Romania & 1990-96 & \\
\hline Russia & 1995, 1998-99 & \\
\hline Senegal & 1988-91 & \\
\hline Singapore & & 1982 \\
\hline \multicolumn{3}{|l|}{ South Africa } \\
\hline Spain & 1977-85 & \\
\hline Sri Lanka & 1989-93 & \\
\hline Sweden & 1991-94 & \\
\hline \multicolumn{3}{|l|}{ Switzerland } \\
\hline Taiwan & $1997-98$ & 1983-84, 1995 \\
\hline \multicolumn{3}{|l|}{ Tanzania } \\
\hline Thailand & 1983-87, 1997-02 & \\
\hline Tunisia & & 1991-95 \\
\hline Turkey & 1982-85, 2000-02 & 1994 \\
\hline Uganda & $1994-96$ & \\
\hline Ukraine & $1997-98$ & \\
\hline United States & & 1988-91 \\
\hline Uruguay & 1981-84, 2002 & \\
\hline \multicolumn{3}{|l|}{ Uzbekistan } \\
\hline Venezuela & 1994-95 & 1976-89 \\
\hline Vietnam & 1997-02 & \\
\hline Zimbabwe & 1995-96 & \\
\hline
\end{tabular}

Source: Honohan and Laeven (2005) 


\begin{tabular}{|c|c|c|c|c|c|c|c|c|}
\hline & 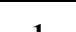 & ? & a & 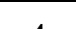 & 5 & 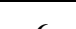 & 7 & 0 \\
\hline$\Delta$ Liberalization (1) & 100 & & & & & & & \\
\hline$\Delta$ Credit Controls (2) & 0.39 & 1.00 & & & & & & \\
\hline$\Delta$ Interest Rate Control (3) & 0.44 & 0.12 & 1.00 & & & & & \\
\hline$\Delta$ Banking Entry (4) & 0.38 & 0.02 & 0.03 & 1.00 & & & & \\
\hline$\Delta$ Privatization (5) & 0.36 & 0.00 & 0.07 & 0.08 & 1.00 & & & \\
\hline$\Delta$ Supervisory Control (6) & 0.36 & 0.03 & -0.03 & 0.10 & -0.01 & 1.00 & & \\
\hline$\Delta$ Capital Controls (7) & 0.47 & 0.05 & 0.13 & 0.08 & 0.05 & 0.00 & 1.00 & \\
\hline$\Delta$ Securities Markets (8) & 0.35 & 0.09 & 0.06 & 0.01 & 0.02 & -0.03 & 0.10 & 1.00 \\
\hline
\end{tabular}




\begin{tabular}{|c|c|c|}
\hline \multicolumn{3}{|c|}{ Table A3. Variable description and sources } \\
\hline \multicolumn{3}{|l|}{ Dependent Variables } \\
\hline Variable: & & Source: \\
\hline Systemic crises & & Honahan and Laeven (2005) \\
\hline Non-systemic crises & & Honahan and Laeven (2005) \\
\hline \multicolumn{3}{|l|}{ Explanatory Variables } \\
\hline Variable: & Expected sign: & Source: \\
\hline Liberalization (overall) & $+/-$ & Abiad et al. (2008) \\
\hline Credit controls & $+/-$ & Abiad et al. (2008) \\
\hline Interest rate control & $+/-$ & Abiad et al. (2008) \\
\hline Banking entry & $+/-$ & Abiad et al. (2008) \\
\hline Privatization & $+/-$ & Abiad et al. (2008) \\
\hline Supervisory control & - & Abiad et al. (2008) \\
\hline Capital controls & $+/-$ & Abiad et al. (2008) \\
\hline Securities markets & $+/-$ & Abiad et al. (2008) \\
\hline Real GDP growth & - & World Development Indicators \\
\hline GDP/Capita & - & World Development Indicators \\
\hline Real interest rate & + & World Development Indicators \\
\hline Inflation & + & World Development Indicators \\
\hline Depreciation & + & World Development Indicators \\
\hline Economic Freedom index & $+/-$ & Gwartney and Lawson (2008) \\
\hline Openness & + & World Development Indicators \\
\hline Bank concentration & - & Beck et al. (2000) \\
\hline Corruption & + & ICRG \\
\hline Money and quasi-money/GDP & $+/-$ & World Development Indicators \\
\hline Credit to private sector/GDP & $+/-$ & World Development Indicators \\
\hline
\end{tabular}




\begin{tabular}{|c|c|c|c|c|c|c|c|c|c|c|c|c|c|c|c|c|c|c|c|c|c|}
\hline \multicolumn{22}{|c|}{ Table A4. Correlation matrix } \\
\hline & 1 & 2 & 3 & 4 & 5 & 6 & 7 & 8 & 9 & 10 & 11 & 12 & 13 & 14 & 15 & 16 & 17 & 18 & 19 & 20 & 21 \\
\hline Systemic crises (1) & 1 & & & & & & & & & & & & & & & & & & & & \\
\hline Non-systemic crises (2) & -0.13 & 1 & & & & & & & & & & & & & & & & & & & \\
\hline Liberalization (overall) (3) & -0.15 & 0.06 & 1 & & & & & & & & & & & & & & & & & & \\
\hline Credit controls (4) & -0.07 & 0.09 & 0.79 & 1 & & & & & & & & & & & & & & & & & \\
\hline Interest rate control (5) & -0.08 & 0.07 & 0.82 & 0.63 & 1 & & & & & & & & & & & & & & & & \\
\hline Banking entry (6) & -0.04 & -0.01 & 0.75 & 0.54 & 0.57 & 1 & & & & & & & & & & & & & & & \\
\hline Privatization (7) & -0.18 & -0.01 & 0.7 & 0.45 & 0.47 & 0.42 & 1 & & & & & & & & & & & & & & \\
\hline Supervisory control (8) & -0.13 & 0.03 & 0.78 & 0.58 & 0.52 & 0.55 & 0.45 & 1 & & & & & & & & & & & & & \\
\hline Capital controls $(9$ & -0.15 & 0.08 & 0.83 & 0.56 & 0.65 & 0.5 & 0.51 & 0.59 & 1 & & & & & & & & & & & & \\
\hline Securities markets (10) & -0.17 & 0.1 & 0.83 & 0.6 & 0.59 & 0.55 & 0.49 & 0.63 & 0.71 & 1 & & & & & & & & & & & \\
\hline Real GDP growth (11) & -0.12 & -0.02 & 0.01 & 0.07 & -0.01 & -0.05 & 0.02 & 0 & 0 & 0 & 1 & & & & & & & & & & \\
\hline GDP/capita (12) & -0.2 & 0.01 & 0.57 & 0.41 & 0.36 & 0.28 & 0.39 & 0.5 & 0.53 & 0.65 & -0.08 & 1 & & & & & & & & & \\
\hline Real interest rate (13) & 0.07 & -0.02 & 0.06 & 0.06 & 0.11 & 0.06 & 0.03 & 0.03 & 0.05 & 0.01 & -0.06 & -0.04 & 1 & & & & & & & & \\
\hline Inflation (14) & 0.14 & 0 & -0.36 & -0.36 & -0.21 & -0.19 & -0.27 & -0.33 & -0.32 & -0.33 & -0.23 & -0.3 & -0.07 & 1 & & & & & & & \\
\hline Depreciation (15) & 0.02 & 0.01 & -0.02 & -0.01 & 0 & -0.01 & -0.02 & -0.03 & -0.02 & -0.03 & -0.02 & -0.02 & 0 & 0.02 & 1 & & & & & & \\
\hline Economic Freedom index (16) & -0.21 & 0.07 & 0.69 & 0.58 & 0.44 & 0.35 & 0.49 & 0.55 & 0.67 & 0.68 & 0.05 & 0.68 & 0.13 & -0.55 & -0.01 & 1 & & & & & \\
\hline Openness (17) & -0.05 & -0.07 & 0.32 & 0.22 & 0.19 & 0.3 & 0.31 & 0.25 & 0.25 & 0.24 & 0.08 & 0.13 & -0.02 & -0.07 & 0.02 & 0.3 & 1 & & & & \\
\hline Bank concentration (18) & -0.05 & -0.12 & -0.14 & -0.06 & -0.18 & -0.05 & -0.1 & -0.08 & -0.12 & -0.13 & 0.06 & 0 & -0.11 & 0.08 & 0.01 & -0.03 & 0.11 & 1 & & & \\
\hline Corruption (19) & -0.22 & 0.03 & 0.44 & 0.32 & 0.31 & 0.23 & 0.31 & 0.36 & 0.39 & 0.46 & -0.05 & 0.67 & 0.01 & -0.21 & 0 & 0.53 & 0.14 & 0.21 & 1 & & \\
\hline Money \& Quasi-money/GDP (20) & -0.03 & -0.02 & -0.05 & -0.09 & -0.09 & -0.09 & 0.05 & -0.03 & -0.02 & -0.02 & -0.04 & -0.01 & 0 & -0.01 & 0 & -0.03 & -0.02 & -0.08 & 0.03 & 1 & \\
\hline Credit to private sector/GDP (21) & -0.08 & -0.05 & 0.52 & 0.38 & 0.32 & 0.27 & 0.44 & 0.42 & 0.49 & 0.56 & -0.03 & 0.74 & -0.03 & -0.35 & 0 & 0.68 & 0.25 & -0.09 & 0.51 & 0.01 & 1 \\
\hline
\end{tabular}




\begin{tabular}{|c|c|c|c|c|c|c|c|c|}
\hline \multicolumn{9}{|c|}{ Table A5. Effect of financial reform on systemic crises - Instrumental Probit results } \\
\hline & & $(1)$ & (2) & (3) & (4) & (5) & (6) & (7) \\
\hline \multirow[t]{2}{*}{ Real GDP growth $(t-1)$} & Coefficient & $-5.148^{* * *}$ & $-4.988 * *$ & -3.172 & $-5.115^{*}$ & $-5.290 * * *$ & $-4.814^{* *}$ & -3.832 \\
\hline & S.E. & 1.982 & 2.361 & 6.578 & 2.699 & 1.969 & 2.076 & 3.247 \\
\hline \multirow[t]{2}{*}{ Log (Initial GDP/capita) } & Coefficient & $-0.301^{* * *}$ & -0.212 & -0.238 & -0.214 & $-0.324 * * *$ & $-0.286 * * *$ & $-0.262 * *$ \\
\hline & S.E. & 0.101 & 0.178 & 0.332 & 0.207 & 0.096 & 0.1 & 0.126 \\
\hline \multirow[t]{2}{*}{ Real interest rate } & Coefficient & 0.006 & 0.008 & 0.005 & 0.004 & 0.005 & 0.005 & 0.004 \\
\hline & S.E. & 0.006 & 0.006 & 0.005 & 0.006 & 0.007 & 0.006 & 0.006 \\
\hline \multirow[t]{2}{*}{ Inflation } & Coefficient & -0.115 & -0.219 & 0.502 & -0.645 & -0.341 & -0.304 & -0.348 \\
\hline & S.E. & 0.906 & 0.867 & 0.889 & 0.959 & 0.859 & 0.913 & 0.941 \\
\hline \multirow[t]{2}{*}{ Depreciation } & Coefficient & 0.509 & 0.619 & 0.435 & 0.661 & 0.714 & 0.685 & 0.71 \\
\hline & S.E. & 0.461 & 0.524 & 0.739 & 0.528 & 0.47 & 0.475 & 0.483 \\
\hline \multirow[t]{2}{*}{ Initial level of liberalization } & Coefficient & -0.033 & $-0.051^{*}$ & -0.002 & -0.055 & -0.027 & -0.031 & -0.032 \\
\hline & S.E. & 0.034 & 0.029 & 0.042 & 0.038 & 0.031 & 0.028 & 0.027 \\
\hline \multirow[t]{2}{*}{ Supervisory control } & Coefficient & -0.035 & -0.063 & -0.213 & -0.021 & 0.016 & -0.017 & -0.079 \\
\hline & S.E. & 0.098 & 0.091 & 0.167 & 0.09 & 0.144 & 0.097 & 0.114 \\
\hline \multirow[t]{2}{*}{ Financial reform (overall) } & Coefficient & -0.092 & & & & & & \\
\hline & S.E. & 0.16 & & & & & & \\
\hline \multirow[t]{2}{*}{ Credit controls reform } & Coefficient & & -0.775 & & & & & \\
\hline & S.E. & & 0.786 & & & & & \\
\hline \multirow[t]{2}{*}{ Interest rate control reform } & Coefficient & & & -0.985 & & & & \\
\hline & S.E. & & & 0.757 & & & & \\
\hline \multirow[t]{2}{*}{ Banking entry reform } & Coefficient & & & & -0.743 & & & \\
\hline & S.E. & & & & 1.142 & & & \\
\hline \multirow[t]{2}{*}{ Privatization reform } & Coefficient & & & & & -0.428 & & \\
\hline & S.E. & & & & & 0.768 & & \\
\hline \multirow[t]{2}{*}{ Capital controls reform } & Coefficient & & & & & & -0.271 & \\
\hline & S.E. & & & & & & 0.402 & \\
\hline \multirow[t]{2}{*}{ Securities markets reform } & Coefficient & & & & & & & -0.634 \\
\hline & S.E. & & & & & & & 0.901 \\
\hline Constant & Coefficient & $1.868^{* * *}$ & $1.558^{* *}$ & 1.894 & $1.572^{* *}$ & $1.893^{* * *}$ & $1.620 * *$ & $1.655^{* * *}$ \\
\hline
\end{tabular}




\begin{tabular}{|c|c|c|c|c|c|c|c|c|}
\hline & S.E. & 0.724 & 0.735 & 1.366 & 0.767 & 0.71 & 0.656 & 0.633 \\
\hline Wald Chi-squared & & $35.887 * * *$ & $72.969 * * *$ & $183.900^{* * *}$ & $63.209 * * *$ & $40.660^{* * *}$ & $40.014^{* * *}$ & $46.675^{* * *}$ \\
\hline Probability (Amemiya-Lee-Newey Statisitc) & & 0.891 & 0.723 & 0.779 & 0.335 & 0.938 & 0.989 & 0.609 \\
\hline
\end{tabular}




\begin{tabular}{|c|c|c|c|c|c|c|c|c|c|}
\hline \multicolumn{10}{|c|}{ Table A6. Effect of financial reform on systemic crises - Developing economies } \\
\hline & & $(1)$ & $(2)$ & $(3)$ & $(4)$ & $(5)$ & $(6)$ & (7) & $(8)$ \\
\hline \multirow[t]{2}{*}{ Real GDP growth $_{(t-1)}$} & Coefficient & $-1.175^{* * *}$ & $-1.265^{* * *}$ & $-1.393 * * *$ & $-1.306 * * *$ & $-1.414^{* * * *}$ & $-1.287 * * *$ & $-1.329 * * *$ & $-1.377 * * *$ \\
\hline & S.E. & 0.313 & 0.358 & 0.36 & 0.356 & 0.359 & 0.359 & 0.356 & 0.361 \\
\hline \multirow[t]{2}{*}{ Log (Initial GDP/capita) } & Coefficient & -0.046 & $-0.065^{*}$ & $-0.066^{*}$ & $-0.074 * *$ & $-0.066 *$ & $-0.067 *$ & $-0.064 *$ & $-0.064 *$ \\
\hline & S.E. & 0.036 & 0.037 & 0.036 & 0.037 & 0.036 & 0.037 & 0.037 & 0.036 \\
\hline \multirow[t]{2}{*}{ Real interest rate } & Coefficient & $0.003^{* * *}$ & $0.003^{* * *}$ & $0.003^{* *}$ & $0.003^{* * *}$ & $0.003^{* * *}$ & $0.003^{* * *}$ & $0.003^{* * *}$ & $0.003^{* * *}$ \\
\hline & S.E. & 0.001 & 0.001 & 0.001 & 0.001 & 0.001 & 0.001 & 0.001 & 0.001 \\
\hline \multirow[t]{2}{*}{ Inflation } & Coefficient & 0.057 & 0.081 & 0.107 & 0.131 & 0.106 & 0.059 & 0.071 & 0.109 \\
\hline & S.E. & 0.165 & 0.172 & 0.17 & 0.17 & 0.17 & 0.172 & 0.17 & 0.17 \\
\hline \multirow[t]{2}{*}{ Depreciation } & Coefficient & $0.218^{*}$ & 0.188 & $0.198^{*}$ & 0.197 & $0.210^{*}$ & $0.205^{*}$ & $0.196 *$ & $0.204^{*}$ \\
\hline & S.E. & 0.117 & 0.121 & 0.12 & 0.121 & 0.12 & 0.12 & 0.119 & 0.12 \\
\hline \multirow[t]{2}{*}{ Initial level of liberalization } & Coefficient & $-0.025 *$ & $-0.028 *$ & $-0.028 *$ & $-0.026^{*}$ & $-0.026 *$ & $-0.026^{*}$ & $-0.028 *$ & $-0.026 *$ \\
\hline & S.E. & 0.014 & 0.015 & 0.015 & 0.015 & 0.014 & 0.015 & 0.015 & 0.014 \\
\hline \multirow[t]{2}{*}{ Supervisory control (SC) } & Coefficient & -0.012 & 0.046 & 0.019 & 0.017 & -0.013 & 0.009 & 0.018 & 0.002 \\
\hline & S.E. & 0.025 & 0.031 & 0.027 & 0.027 & 0.028 & 0.027 & 0.026 & 0.028 \\
\hline \multirow[t]{2}{*}{ Reform (LR) (overall) } & Coefficient & & -0.003 & & & & & & \\
\hline & S.E. & & 0.007 & & & & & & \\
\hline \multirow[t]{2}{*}{$\mathrm{SC}^{*} \mathrm{LR}$} & Coefficient & & $-0.026^{* * *}$ & & & & & & \\
\hline & S.E. & & 0.01 & & & & & & \\
\hline \multirow[t]{2}{*}{ Credit controls reform (CR) } & Coefficient & & & 0.031 & & & & & \\
\hline & S.E. & & & 0.023 & & & & & \\
\hline \multirow[t]{2}{*}{$\mathrm{SC} * \mathrm{CR}$} & Coefficient & & & $-0.055^{* *}$ & & & & & \\
\hline & S.E. & & & 0.028 & & & & & \\
\hline \multirow[t]{2}{*}{ Interest rate control reform (IR) } & Coefficient & & & & -0.014 & & & & \\
\hline & S.E. & & & & 0.018 & & & & \\
\hline \multirow[t]{2}{*}{ SC*IR } & Coefficient & & & & $-0.082 * * *$ & & & & \\
\hline & S.E. & & & & 0.03 & & & & \\
\hline \multirow[t]{2}{*}{ Banking entry reform (BR) } & Coefficient & & & & & -0.019 & & & \\
\hline & S.E. & & & & & 0.025 & & & \\
\hline$S C * B R$ & Coefficient & & & & & 0.035 & & & \\
\hline
\end{tabular}




\begin{tabular}{|c|c|c|c|c|c|c|c|c|c|}
\hline & S.E. & & & & & 0.029 & & & \\
\hline \multirow{2}{*}{ Privatization reform (PR) } & Coefficient & & & & & & -0.046 & & \\
\hline & S.E. & & & & & & 0.03 & & \\
\hline \multirow[t]{2}{*}{$\mathbf{S C}^{*} \mathbf{P R}$} & Coefficient & & & & & & -0.032 & & \\
\hline & S.E. & & & & & & 0.031 & & \\
\hline \multirow[t]{2}{*}{ Capital controls reform (CapR) } & Coefficient & & & & & & & 0.001 & \\
\hline & S.E. & & & & & & & 0.023 & \\
\hline \multirow[t]{2}{*}{ SC $^{*}$ CapR } & Coefficient & & & & & & & $-0.079 * * *$ & \\
\hline & S.E. & & & & & & & 0.03 & \\
\hline \multirow[t]{2}{*}{ Securities markets reform (SR) } & Coefficient & & & & & & & & -0.012 \\
\hline & S.E. & & & & & & & & 0.034 \\
\hline \multirow[t]{2}{*}{$\mathbf{S C} * \mathbf{S R}$} & Coefficient & & & & & & & & -0.013 \\
\hline & S.E. & & & & & & & & 0.04 \\
\hline No. of Observations & & 1000 & 944 & 944 & 944 & 944 & 944 & 944 & 944 \\
\hline No. of Countries & & 61 & 61 & 61 & 61 & 61 & 61 & 61 & 61 \\
\hline Wald Chi-squared & & $37.252^{* * *}$ & $51.463^{* * * *}$ & $43.737 * * *$ & $52.390 * * *$ & $41.651 * * *$ & $49.291 * * *$ & $49.829 * * *$ & $41.292 * * *$ \\
\hline L Ratio Test & & $132.369 * * *$ & $134.574^{* * *}$ & $133.979 * * *$ & $132.115^{* * *}$ & $133.158^{* * * *}$ & $140.819^{* * *}$ & $136.700^{* * *}$ & $126.530^{* * * *}$ \\
\hline Brier Score & & 0.181 & 0.177 & 0.179 & 0.177 & 0.179 & 0.179 & 0.177 & 0.179 \\
\hline
\end{tabular}




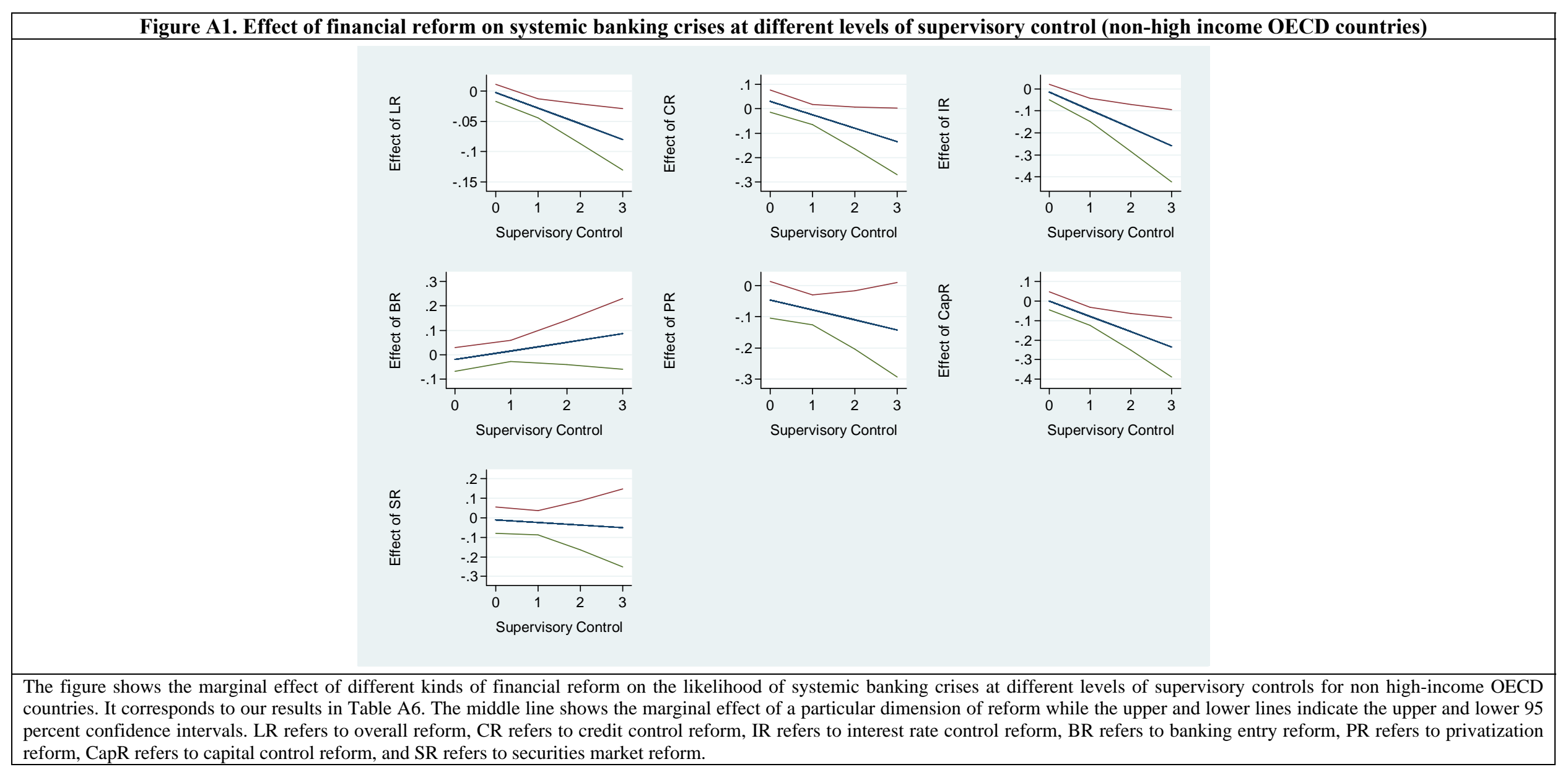




\section{CESifo Working Paper Series}

for full list see www.cesifo-group.org/wp

(address: Poschingerstr. 5, 81679 Munich, Germany, office@cesifo.de)

2809 Johan Eyckmans and Cathrine Hagem, The European Union's Potential for Strategic Emissions Trading through Minimal Permit Sale Contracts, September 2009

2810 Ruediger Bachmann and Christian Bayer, The Cross-section of Firms over the Business Cycle: New Facts and a DSGE Exploration, October 2009

2811 Slobodan Djajić and Michael S. Michael, Temporary Migration Policies and Welfare of the Host and Source Countries: A Game-Theoretic Approach, October 2009

2812 Devis Geron, Social Security Incidence under Uncertainty Assessing Italian Reforms, October 2009

2813 Max-Stephan Schulze and Nikolaus Wolf, Economic Nationalism and Economic Integration: The Austro-Hungarian Empire in the Late Nineteenth Century, October 2009

2814 Emilia Simeonova, Out of Sight, Out of Mind? The Impact of Natural Disasters on Pregnancy Outcomes, October 2009

2815 Dan Kovenock and Brian Roberson, Non-Partisan 'Get-Out-the-Vote' Efforts and Policy Outcomes, October 2009

2816 Sascha O. Becker, Erik Hornung and Ludger Woessmann, Catch Me If You Can: Education and Catch-up in the Industrial Revolution, October 2009

2817 Horst Raff and Nicolas Schmitt, Imports, Pass-Through, and the Structure of Retail Markets, October 2009

2818 Paul De Grauwe and Daniel Gros, A New Two-Pillar Strategy for the ECB, October 2009

2819 Guglielmo Maria Caporale, Thouraya Hadj Amor and Christophe Rault, International Financial Integration and Real Exchange Rate Long-Run Dynamics in Emerging Countries: Some Panel Evidence, October 2009

2820 Saša Žiković and Randall K. Filer, Hybrid Historical Simulation VaR and ES: Performance in Developed and Emerging Markets, October 2009

2821 Panu Poutvaara and Andreas Wagener, The Political Economy of Conscription, October 2009

2822 Steinar Holden and Åsa Rosén, Discrimination and Employment Protection, October 2009 
2823 David G. Mayes, Banking Crisis Resolution Policy - Lessons from Recent Experience Which elements are needed for robust and efficient crisis resolution?, October 2009

2824 Christoph A. Schaltegger, Frank Somogyi and Jan-Egbert Sturm, Tax Competition and Income Sorting: Evidence from the Zurich Metropolitan Area, October 2009

2825 Natasa Bilkic, Thomas Gries and Margarethe Pilichowski, Stay in School or Start Working? - The Human Capital Investment Decision under Uncertainty and Irreversibility, October 2009

2826 Hartmut Egger and Udo Kreickemeier, Worker-Specific Effects of Globalisation, October 2009

2827 Alexander Fink and Thomas Stratmann, Institutionalized Bailouts and Fiscal Policy: The Consequences of Soft Budget Constraints, October 2009

2828 Wolfgang Ochel and Anja Rohwer, Reduction of Employment Protection in Europe: A Comparative Fuzzy-Set Analysis, October 2009

2829 Rainald Borck and Martin Wimbersky, Political Economics of Higher Education Finance, October 2009

2830 Torfinn Harding and Frederick van der Ploeg, Is Norway's Bird-in-Hand Stabilization Fund Prudent Enough? Fiscal Reactions to Hydrocarbon Windfalls and Graying Populations, October 2009

2831 Klaus Wälde, Production Technologies in Stochastic Continuous Time Models, October 2009

2832 Biswa Bhattacharyay, Dennis Dlugosch, Benedikt Kolb, Kajal Lahiri, Irshat Mukhametov and Gernot Nerb, Early Warning System for Economic and Financial Risks in Kazakhstan, October 2009

2833 Jean-Claude Trichet, The ECB's Enhanced Credit Support, October 2009

2834 Hans Gersbach, Campaigns, Political Mobility, and Communication, October 2009

2835 Ansgar Belke, Gunther Schnabl and Holger Zemanek, Real Convergence, Capital Flows, and Competitiveness in Central and Eastern Europe, October 2009

2836 Bruno S. Frey, Simon Luechinger and Alois Stutzer, The Life Satisfaction Approach to Environmental Valuation, October 2009

2837 Christoph Böhringer and Knut Einar Rosendahl, Green Serves the Dirtiest: On the Interaction between Black and Green Quotas, October 2009

2838 Katarina Keller, Panu Poutvaara and Andreas Wagener, Does Military Draft Discourage Enrollment in Higher Education? Evidence from OECD Countries, October 2009 
2839 Giovanni Cespa and Xavier Vives, Dynamic Trading and Asset Prices: Keynes vs. Hayek, October 2009

2840 Jan Boone and Jan C. van Ours, Why is there a Spike in the Job Finding Rate at Benefit Exhaustion?, October 2009

2841 Andreas Knabe, Steffen Rätzel and Stephan L. Thomsen, Right-Wing Extremism and the Well-Being of Immigrants, October 2009

2842 Andrea Weber and Christine Zulehner, Competition and Gender Prejudice: Are Discriminatory Employers Doomed to Fail?, November 2009

2843 Hadi Salehi Esfahani, Kamiar Mohaddes and M. Hashem Pesaran, Oil Exports and the Iranian Economy, November 2009

2844 Ruediger Bachmann and Christian Bayer, Firm-Specific Productivity Risk over the Business Cycle: Facts and Aggregate Implications, November 2009

2845 Guglielmo Maria Caporale, Burcu Erdogan and Vladimir Kuzin, Testing for Convergence in Stock Markets: A Non-Linear Factor Approach, November 2009

2846 Michèle Belot and Jan Fidrmuc, Anthropometry of Love - Height and Gender Asymmetries in Interethnic Marriages, November 2009

2847 Volker Nitsch and Nikolaus Wolf, Tear Down this Wall: On the Persistence of Borders in Trade, November 2009

2848 Jan K. Brueckner and Stef Proost, Carve-Outs Under Airline Antitrust Immunity, November 2009

2849 Margarita Katsimi and Vassilis Sarantides, The Impact of Fiscal Policy on Profits, November 2009

2850 Scott Alan Carson, The Relationship between Stature and Insolation: Evidence from Soldiers and Prisoners, November 2009

2851 Horst Raff and Joachim Wagner, Intra-Industry Adjustment to Import Competition: Theory and Application to the German Clothing Industry, November 2009

2852 Erkki Koskela, Impacts of Labor Taxation with Perfectly and Imperfectly Competitive Labor Markets under Flexible Outsourcing, November 2009

2853 Cletus C. Coughlin and Dennis Novy, Is the International Border Effect Larger than the Domestic Border Effect? Evidence from U.S. Trade, November 2009

2854 Johannes Becker and Clemens Fuest, Source versus Residence Based Taxation with International Mergers and Acquisitions, November 2009

2855 Andreas Hoffmann and Gunther Schnabl, A Vicious Cycle of Manias, Crashes and Asymmetric Policy Responses - An Overinvestment View, November 2009 
2856 Xavier Vives, Strategic Supply Function Competition with Private Information, November 2009

2857 M. Hashem Pesaran and Paolo Zaffaroni, Optimality and Diversifiability of Mean Variance and Arbitrage Pricing Portfolios, November 2009

2858 Davide Sala, Philipp J.H. Schröder and Erdal Yalcin, Market Access through Bound Tariffs, November 2009

2859 Ben J. Heijdra and Pim Heijnen, Environmental Policy and the Macroeconomy under Shallow-Lake Dynamics, November 2009

2860 Enrico Spolaore, National Borders, Conflict and Peace, November 2009

2861 Nina Czernich, Oliver Falck, Tobias Kretschmer and Ludger Woessmann, Broadband Infrastructure and Economic Growth, December 2009

2862 Evžen Kočenda and Martin Vojtek, Default Predictors and Credit Scoring Models for Retail Banking, December 2009

2863 Christian Gollier and Martin L. Weitzman, How Should the Distant Future be Discounted when Discount Rates are Uncertain?, December 2009

2864 Tiberiu Dragu and Mattias Polborn, Terrorism Prevention and Electoral Accountability, December 2009

2865 Torfinn Harding and Beata Smarzynska Javorcik, A Touch of Sophistication: FDI and Unit Values of Exports, December 2009

2866 Matthias Dischinger and Nadine Riedel, There's no Place like Home: The Profitability Gap between Headquarters and their Foreign Subsidiaries, December 2009

2867 Andreas Haufler and Frank Stähler, Tax Competition in a Simple Model with Heterogeneous Firms: How Larger Markets Reduce Profit Taxes, December 2009

2868 Steinar Holden, Do Choices Affect Preferences? Some Doubts and New Evidence, December 2009

2869 Alberto Asquer, On the many Ways Europeanization Matters: The Implementation of the Water Reform in Italy (1994-2006), December 2009

2870 Choudhry Tanveer Shehzad and Jakob De Haan, Financial Reform and Banking Crises, December 2009 